\title{
Advanced Synthesis and Characterization of Vanadia/Titania Catalysts through a Molecular Approach
}

\author{
Eleni Tella ${ }^{1}$, Antonios Trimpalis ${ }^{2}$, Athanasios Tsevis ${ }^{3}$, Christos Kordulis ${ }^{1,3,4} \mathbb{D}$, Alexis Lycourghiotis ${ }^{1}$, \\ Soghomon Boghosian 2,3,4 (D) and Kyriakos Bourikas ${ }^{3, *(D)}$ \\ 1 Department of Chemistry, University of Patras, GR-26504 Patras, Greece; tella4214@yahoo.gr (E.T.); \\ kordulis@upatras.gr (C.K.); alycour@upatras.gr (A.L.) \\ 2 Department of Chemical Engineering, University of Patras, GR-26504 Patras, Greece; \\ atribalis@gmail.com (A.T.); bogosian@chemeng.upatras.gr (S.B.) \\ 3 School of Science and Technology, Hellenic Open University, Tsamadou 13-15, GR-26222 Patras, Greece; \\ ntsevis@yahoo.gr \\ 4 Foundation for Research and Technology, Institute of Chemical Engineering Science (FORTH/ICE-HT), \\ Stadiou Str., Platani, P.O. Box 1414, GR-26500 Patras, Greece \\ * Correspondence: bourikas@eap.gr; Tel.: +30-261-036-7527
}

\section{check for} updates

Citation: Tella, E.; Trimpalis, A.; Tsevis, A.; Kordulis, C.; Lycourghiotis, A.; Boghosian, S.; Bourikas, K. Advanced Synthesis and Characterization of Vanadia/Titania Catalysts through a Molecular Approach. Catalysts 2021, 11, 322 https://doi.org/10.3390/catal11030322

\section{Academic Editors:}

Jean-François Lamonier and Michalis Konsolakis

Received: 29 January 2021

Accepted: 25 February 2021

Published: 2 March 2021

Publisher's Note: MDPI stays neutral with regard to jurisdictional claims in published maps and institutional affiliations.

Copyright: (c) 2021 by the authors. Licensee MDPI, Basel, Switzerland. This article is an open access article distributed under the terms and conditions of the Creative Commons Attribution (CC BY) license (https:// creativecommons.org/licenses/by/ $4.0 /)$
Abstract: Vanadia/titania catalysts were synthesized by the equilibrium deposition filtration (EDF) method, which is a synthesis route that follows a molecular-level approach. The type of interfacial deposition as well as the interfacial speciation of the deposited oxo- $\mathrm{V}(\mathrm{V})$ species were determined by means of a model that takes into account experimental "proton-ion" curves and "adsorption edges". It is shown that at $\mathrm{pH} \geq 9.5$, the deposition proceeds exclusively through the formation of mono-substituted inner sphere monomeric species in an "umbrella"-like Ti-OV(OH $)_{2} \mathrm{O}$ configuration, whilst with lowering of the $\mathrm{pH}$, a second species, namely the disubstituted inner sphere quadrameric species in a (Ti-O) $)_{2} \mathrm{~V}_{4} \mathrm{O}_{10}$ configuration possessing two mono-oxo $\mathrm{V}=\mathrm{O}$ and two di-oxo $\mathrm{V}(=\mathrm{O})_{2}$ terminations gradually prevails, which is in co-existence with the monomeric species. Raman spectroscopy is used for verifying the solution speciation, which is different compared to the interfacial speciation of the deposited oxo- $\mathrm{V}(\mathrm{V})$ species. Furthermore, in situ Raman spectroscopy was used to verify the model-predicted interfacial speciation of the deposited oxo- $\mathrm{V}(\mathrm{V})$ species and to monitor the temperature-dependent evolution up to $430^{\circ} \mathrm{C}$. Hence, a controlled formation of a specific vanadia species on a titania surface is enabled, which, depending on the synthesis conditions, can result in specific catalyst characteristics and thus possibly different catalytic behavior for a specific reaction.

Keywords: vanadia/titania; supported transition metal oxide catalysts; vanadium oxide; titanium oxide; advanced synthesis; Raman spectroscopy

\section{Introduction}

Supported vanadium oxide catalysts are among the most widely studied functional materials for several catalytic applications [1]. More specifically, vanadia supported on titania catalysts is a very important material for many industrial processes, including those of environmental interest. It is worth mentioning dehydrogenation reactions [2-5], oxidation processes [6-11], water treatment through photocatalysis [12,13], and electrocatalysis [14]. However, the technology in which these catalysts are widely used is the selective catalytic reduction (SCR) of $\mathrm{NO}_{x}$, using mainly $\mathrm{NH}_{3}$ as a reductant. It is a wellestablished technology for the after-treatment control of the emissions of $\mathrm{NO}_{x}$ formed during combustion in both mobile sources (e.g., diesel engines) and stationary sources (e.g., power plants) [15-18]. Moreover, in the last few years, a new challenging trend is the use of these catalysts for the abatement of multi-pollutants, including $\mathrm{NO}_{\mathrm{x}}$, in the flue gas pollution control technology $[19,20]$.

Although the $\mathrm{VO}_{\mathrm{x}} / \mathrm{TiO}_{2}$ catalytic system has been studied extensively in the past [21-23], the research effort to improve the efficiency of the SCR process over these catalysts is still of 
great topical interest, since the legislation becomes increasingly stricter, requiring emission control of $\mathrm{NO}_{x}$ due to their very negative impact on the environment through to smog formation, acid rain formation, and depletion of the ozone layer. Moreover, their use for both stationary and mobile sources with different characteristics and requirements has kept the scientific research interest for these catalysts at a very high level, despite their long history $[21,22,24]$. The research effort is directed to the development of catalysts with high SCR efficiency, broad operation temperature window, superb durability, hydrothermal stability, and high resistance against $\mathrm{SO}_{2}$ /alkali/heavy metals [21,22]. To achieve these goals as well as fully elucidate the SCR mechanism, the scientific community strives for structure-reactivity relationships by focusing on the study of the structural properties of the active sites [25-29], tries to find the optimum surface density of vanadium [30], synthesizes binary systems concerning either the active phase $\left(\mathrm{VO}_{\mathrm{x}}\right)$ or the support $\left(\mathrm{TiO}_{2}\right)[18,31-34]$, dopes the support [35], synthesizes metal vanadates [36], and tries to find the optimum thermal treatment of the catalysts [37] etc.

It is generally agreed that a very crucial factor in the SCR process (as well as in the other above-mentioned catalytic processes) is the identification of the vanadia active site, which, despite the extensive research, is still under debate. In order to reach this target, one has to begin from the first stage of the whole process, namely the catalysts synthesis. Two main routes are followed toward this direction: the use of model systems that provide full catalytic functionality but exhibit reduced chemical complexity $[25-28,38,39]$ and the preparation of tailor-made catalysts using advanced synthesis methods [3,4]. The present study belongs to the second context. The superior efficiency of vanadia/titania catalysts prepared by advanced synthesis methods compared to the conventional ones has been reported repeatedly in the literature $[18,21,34,40]$. Moreover, excellent reviews and book chapters have been published on this subject, showing how the more sophisticated synthesis methods of supported catalysts can help us rationalize their synthesis, improve their efficiency, and control the formation of their active sites [41-48]. In this context, in the last years, we have developed supported transition metal catalysts through a molecular approach, using the equilibrium deposition filtration method (EDF), in order to fully control the impregnation step and specify the transition metal ionic species deposited on the support surface [49-53]. The present study is concerned with an effort to follow the formation of the vanadia site from the first to the final step of the catalyst synthesis procedure using the EDF method. To this end, the interfacial deposition process of the vanadates on titania (taking place in the impregnation step) is modeled based on experimental results, and the model results are verified by Raman spectroscopy, which is known as a powerful tool for elucidating the structural information of supported metal oxides and has been used extensively for studying vanadia SCR catalysts at the molecular level [54-63].

Hence, in the present work, first, the speciation of the oxo- $\mathrm{V}(\mathrm{V})$ species in the precursor impregnation solutions is determined in conditions relevant to the follow up impregnation step by means of a model taking into account pertinent experimental information, and the precursor solution speciation is verified by Raman spectroscopy. Secondly (and more importantly), the type of interfacial deposition of oxo- $\mathrm{V}(\mathrm{V})$ species at the interface between $\mathrm{TiO}_{2}$ (P25) and the precursor electrolyte solution is investigated and a prediction of the interfacial speciation of deposited oxo- $\mathrm{V}(\mathrm{V})$ species is reached based on experimental results previously reported [64]. Then, in situ Raman spectroscopy is used for verifying the interfacial speciation of the as-prepared by the EDF method wet $\mathrm{H}_{K} \mathrm{~V}_{X} \mathrm{O}_{Y}{ }^{\mathrm{Z}-} / \mathrm{TiO}_{2}$ pastes and for monitoring the temperature-dependent evolution of the $\mathrm{V}(\mathrm{V})$ species at temperatures up to $430{ }^{\circ} \mathrm{C}$.

\section{Results and Discussion}

\subsection{Solution Speciation of Vanadates}

Aqueous solutions of vanadium contain a variety of vanadium species (vanadates), such as monomers, quadramers, quintamers, decamers, etc., depending on the conditions. 
Figure 1 shows the schematic representation of the structures of some representative vanadates.

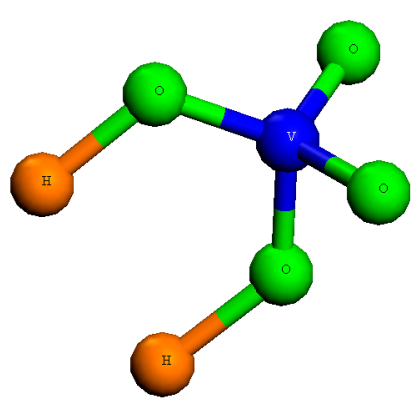

(a)

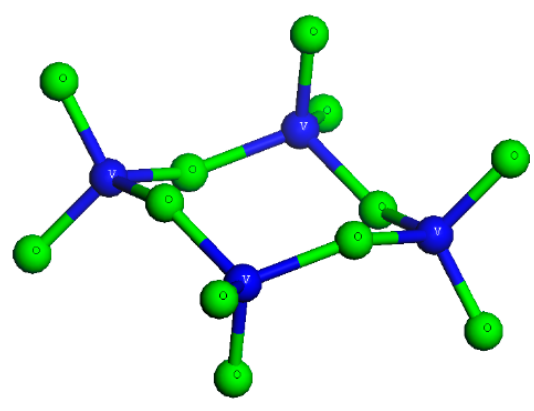

(b)

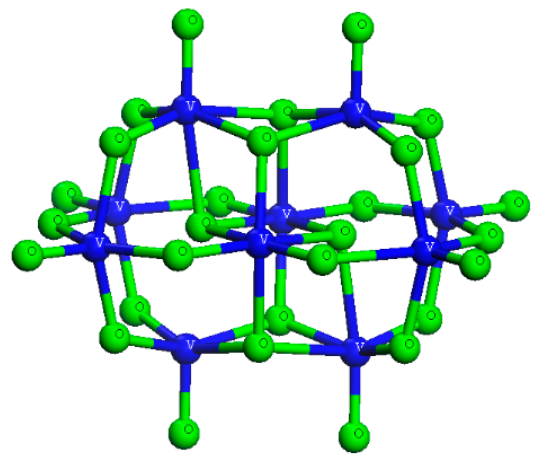

(c)

Figure 1. Structure of (a) the monomer $\mathrm{H}_{2} \mathrm{VO}_{4}{ }^{-}$, (b) the quadramer $\left(\mathrm{V}_{4} \mathrm{O}_{12}{ }^{4-}\right)$, and (c) the decamer $\left(\mathrm{HV}_{10} \mathrm{O}_{28}{ }^{5-}\right.$ or $\mathrm{NaHV}_{10} \mathrm{O}_{28}{ }^{4-}$ ) vanadates.

Using Visual MINTEQ [65], the solution speciation of $V(V)$ was determined under conditions identical to those of the deposition experiments (adsorption edges). Table 1 gives the equations of the mass action law of the main species of vanadium used by the aforementioned computer program.

Table 1. The main $\mathrm{V}(\mathrm{V})$ oxo-species present in solution in the $\mathrm{pH}$ range 4-10, the solution components of the formation reactions, the exponential values for these components, and the values of the corresponding formation constants.

\begin{tabular}{|c|c|c|c|c|c|}
\hline \multirow{2}{*}{$\begin{array}{c}\text { Vanadium Species } \\
-\end{array}$} & \multicolumn{4}{|c|}{ Solution Components } & \multirow{2}{*}{$\log K$} \\
\hline & $\mathrm{HVO}_{4}^{2-}$ & $\mathrm{H}^{+}$ & $\mathrm{Na}^{+}$ & $\mathrm{H}_{2} \mathrm{O}$ & \\
\hline $\mathrm{H}_{2} \mathrm{VO}_{4}^{-}$ & 1 & 1 & 0 & 0 & 8.75 \\
\hline $\mathrm{H}_{2} \mathrm{~V}_{2} \mathrm{O}_{7}^{\frac{4}{2}-}$ & 2 & 2 & 0 & -1 & 19.8 \\
\hline $\mathrm{V}_{4} \mathrm{O}_{12}^{4-}$ & 4 & 4 & 0 & -4 & 42.6 \\
\hline $\mathrm{HV}_{10} \mathrm{O}_{28}^{5-}$ & 10 & 15 & 0 & -12 & 141.5 \\
\hline $\mathrm{NaHV}_{10} \mathrm{O}_{28}^{4-}$ & 10 & 15 & 1 & -12 & 143.68 \\
\hline
\end{tabular}

The concentration [S] (mol/L) of each species, compiled in Table 1, is calculated by reading the table horizontally and using the general Equation (1).

$$
[S]=10^{\log K} \prod_{k}\left[C_{k}\right]^{n_{k}}
$$

$C_{k}$ is the concentration of a solution component $\left(\mathrm{HVO}_{4}{ }^{2-}, \mathrm{H}^{+}, \mathrm{Na}^{+}, \mathrm{H}_{2} \mathrm{O}\right)$ illustrated in the first series of the table. The value of the exponent, $n_{k}$, for each component is given in Table 1. To calculate the concentrations of all $\mathrm{V}(\mathrm{V})$ oxo-species, at each value of the solution parameters, we entered in the computer program (Visual MINTEQ) the values of $\mathrm{pH}(4-10)$, the total concentration of $\mathrm{V}(\mathrm{V})\left(2 \times 10^{-2} \mathrm{M}, 3 \times 10^{-3} \mathrm{M}\right.$ and $\left.6 \times 10^{-3} \mathrm{M}\right)$, as well as the ionic strength of the solution $(\mathrm{I}=0.1 \mathrm{~N})$. The program solved the equations in Table 1 by incorporating the values of the constants of the species $(\log K)$ from the literature as well as the mass balance equations for each component shown in Table 1. The results are presented in Figure 2a,b as a double diagram. In the left diagram, the variation of the concentration $([\mathrm{S}](\mathrm{mol} / \mathrm{L}))$ of the main vanadium species with the $\mathrm{pH}$ is presented, whereas the right one presents the distribution of total vanadium among the different species in the solution. The two diagrams are equivalent. Corresponding diagrams for two lower total $\mathrm{V}(\mathrm{V})$ concentrations are given in the Supplementary Materials (Figure S1). 


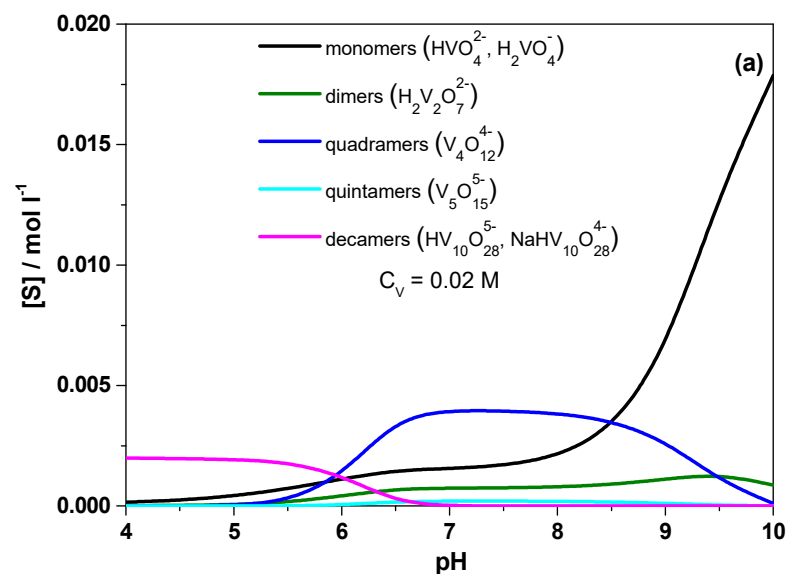

(a)

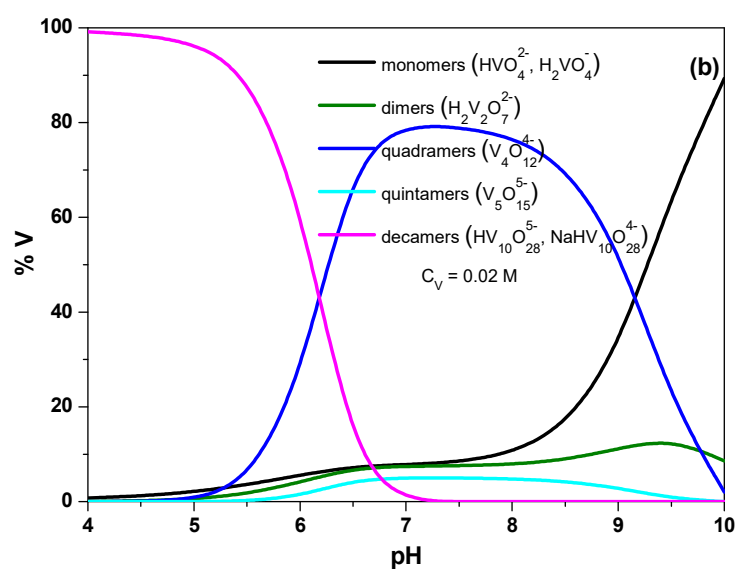

(b)

Figure 2. (a) Variation of the concentration, [S] (mol/L), of the main vanadium species with the $\mathrm{pH}$, and (b) the distribution of total vanadium among the different species in the solution $\left(\mathrm{C}_{\mathrm{V}}=0.02 \mathrm{M}, \mathrm{I}=0.1 \mathrm{M} \mathrm{NaNO}_{3}\right)$.

Figure $\mathrm{S} 1$ shows that vanadium is present almost exclusively in the form of monomers at low total $\mathrm{V}$ concentrations $(0.003 \mathrm{M}$ and $0.006 \mathrm{M})$ and high $\mathrm{pH}$ values ( $>9)$. At such high $\mathrm{pH}$ values, quadramers also have a significant presence at high total $\mathrm{V}$ concentrations (i.e., $0.02 \mathrm{M}$ ) (Figure 2). On the contrary, at low $\mathrm{pH}$ values $(<5)$ and in the whole $\mathrm{V}$ concentration range studied, vanadium is mainly present in the form of the decamers (Figure 2 and Figure S1). The speciation is more complicated at the intermediate $\mathrm{pH}$ range (5-9). Vanadium is mainly distributed among the monomers, the dimers, and the quadramers, with much less contribution of the quintamers. As the total $\mathrm{V}$ concentration increases, the concentration of the quadramers increase at the expense of that of the monomers and dimers (Figure 2 and Figure S1).

\subsection{Kinetic Results}

The results of the kinetic experiments are shown in Figure 3. We can conclude that regardless of $\mathrm{pH}$, either at $\mathrm{pH}$ where the surface is positively charged (4.0), at $\mathrm{pH}$ where it is negatively charged (9.0), or at $\mathrm{pH}$ that is almost neutral (6.5), a very fast adsorption process takes place which is accomplished within the first $5 \mathrm{~min}$. The above show a very strong chemical affinity between titanium oxide and vanadates.

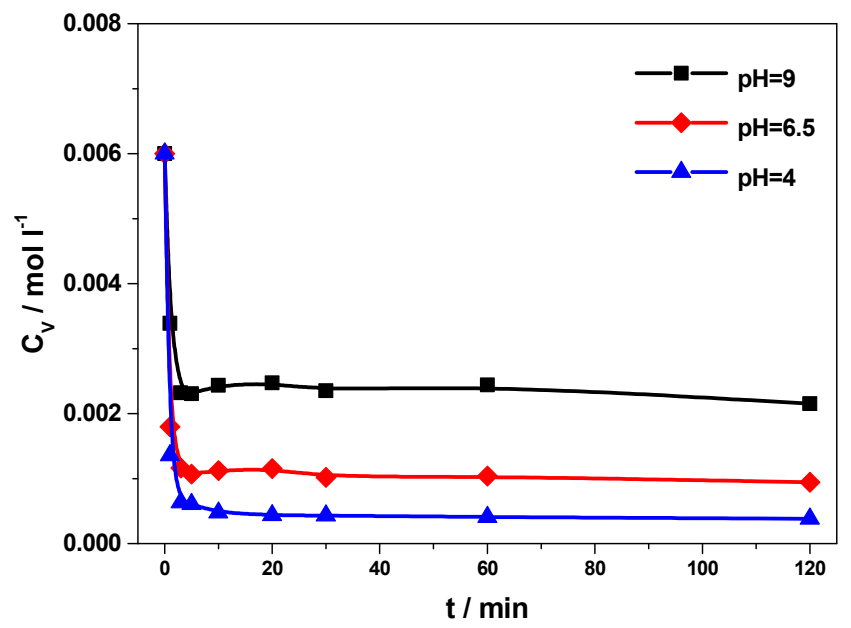

Figure 3. Kinetic curves of deposition of $\mathrm{V}$ on the titania surface at three different $\mathrm{pH}$ values of the impregnation solution and total $\mathrm{V}$ concentration equal to $6 \times 10^{-3} \mathrm{M}$. 


\subsection{Modeling the Deposition of Vanadates on Titania Surface}

The modeling of the deposition of vanadates on the titania surface was based on a picture for the "titania/electrolyte solution" interface obtained from a previous work [66]. More specifically, the modeling adopted the values of the surface ionization constants of titania and the parameters of the "titania/electrolyte solution" interface in the absence of the vanadates. These can be found in Table A1. Upon modeling, the adjustable parameters of the simulation were the type of the adsorption or reaction processes involved in the deposition, the formation constants of the deposited $\mathrm{V}(\mathrm{V})$ oxo-species, and the charge distribution of these species at the various planes of the interface [66]. The full set of the equations adopted in the modeling can be found in Table A1.

The first step of the modeling process was the simulation of the "proton-ion" data. The "proton-ion" curves are linear plots of the "amount of the $\mathrm{H}^{+}$ions adsorbed versus the amount of the $\mathrm{V}$ deposited" at constant $\mathrm{pH}$ and under conditions favoring complete deposition of the $\mathrm{V}(\mathrm{V})$ oxo-species at the titania surface. The last can be achieved by working at too low $\mathrm{V}$ concentrations and a very high solid/solution ratio [41,49,64]. A successful fitting of these curves is only possible if the right deposition mechanism is adopted in the simulation [49-53]. This is the case in Figure 4. Similar fits have been achieved for all $\mathrm{pH}$ values (see Figure S2 in the Supplementary Materials).

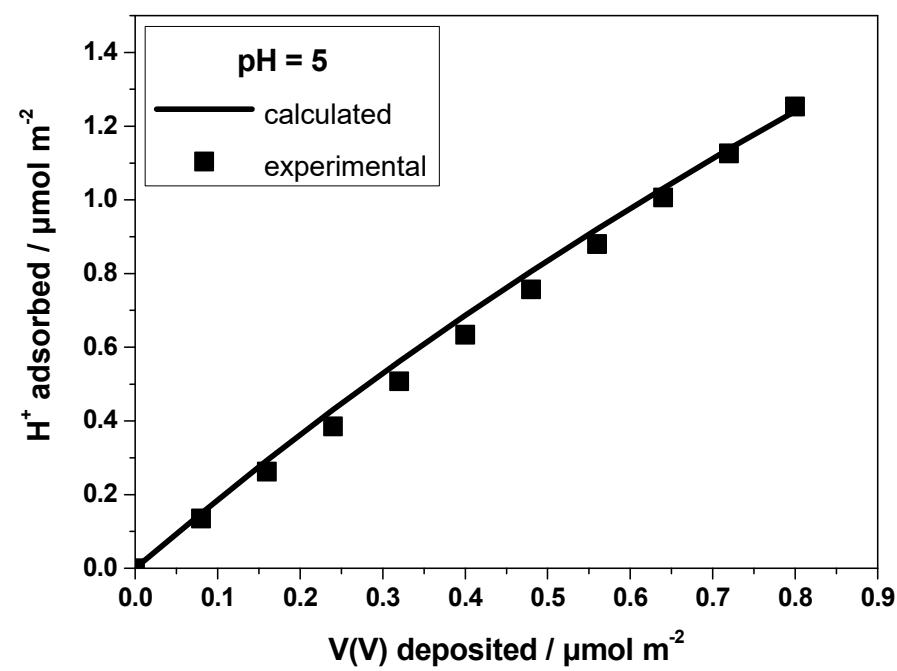

Figure 4. Amount of the $\mathrm{H}+$ ions adsorbed vs. the amount of the deposited $\mathrm{V}(\mathrm{V})$ for various $\mathrm{pH}$ values. Points represent experimental data and solid lines correspond to calculated curves on the basis of the deposition mechanism finally adopted in the simulation.

The very good fitting of the "proton-ion" curves allowed the elucidation of the deposition mechanism of vanadates on titania surface, at too low $\mathrm{V}$ concentrations. This mechanism is described by Equilibria (2) and (3), which involve only vanadium monomers, since only these species are present in solutions of too low concentrations.

$$
\begin{gathered}
\mathrm{TiO}^{-0.35}+2 \mathrm{H}^{+}+\mathrm{H}_{2} \mathrm{VO}_{4}^{-} \stackrel{\mathrm{K}_{\mathrm{T} 1}}{\leftrightarrow} \mathrm{TiOV}(\mathrm{OH})_{2} \mathrm{O}^{+0.65}+\mathrm{H}_{2} \mathrm{O} \\
2 \mathrm{TiO}^{-0.35}+4 \mathrm{H}^{+}+\mathrm{H}_{2} \mathrm{VO}_{4}^{-} \stackrel{\mathrm{K}_{\mathrm{T} 2}}{\leftrightarrow}(\mathrm{TiO})_{2} \mathrm{~V}(\mathrm{OH})_{2}{ }^{+2.3}+2 \mathrm{H}_{2} \mathrm{O}
\end{gathered}
$$

According to these equilibria, the monomers $\mathrm{H}_{2} \mathrm{VO}_{4}{ }^{-}$are deposited on the terminal hydroxyls of titania, forming mono-substituted and disubstituted inner sphere complexes. A schematic representation of the structures of the deposited species is illustrated in Figure 5. The anatase $\left(\begin{array}{lll}1 & 0 & 0\end{array}\right)$ crystal termination, one of the two majority crystal faces of anatase, has been chosen to exemplify these structures. Similar pictures may be obtained by considering the other majority crystal termination of the anatase $\left(\begin{array}{lll}1 & 0 & 1\end{array}\right)$. 


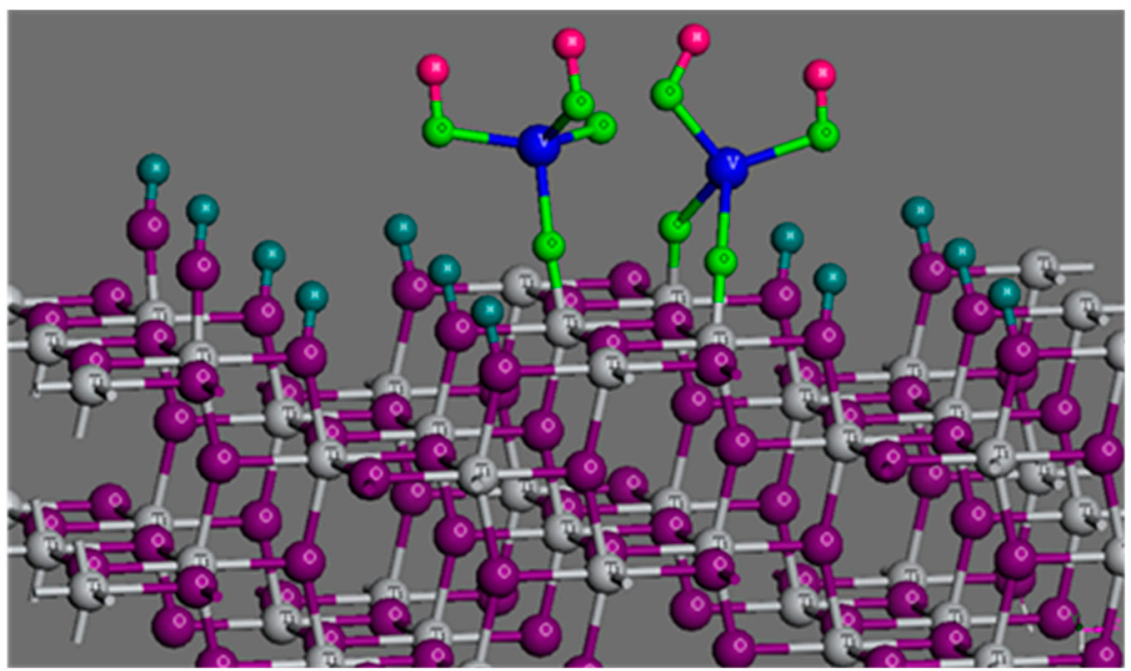

Figure 5. Local structures of the deposited V monomers on the $\left(\begin{array}{lll}1 & 0 & 0\end{array}\right)$ crystal termination of anatase.

The second step of the modeling process comes from a logical question raised at this point. This is whether the deposition process may be described exclusively by Equilibria (2) and (3) even at high V solution concentrations. In order to answer this question, we tried to simulate the adsorption edges, which cover a broad range of $\mathrm{pH}$ and $\mathrm{V}$ concentrations. The model curves failed to fit the experimental data. Thus, we forced to take into account all the vanadates present in the impregnation solutions (Figure 2). The best fit of the model curves to the experimental data is presented in Figure 6.

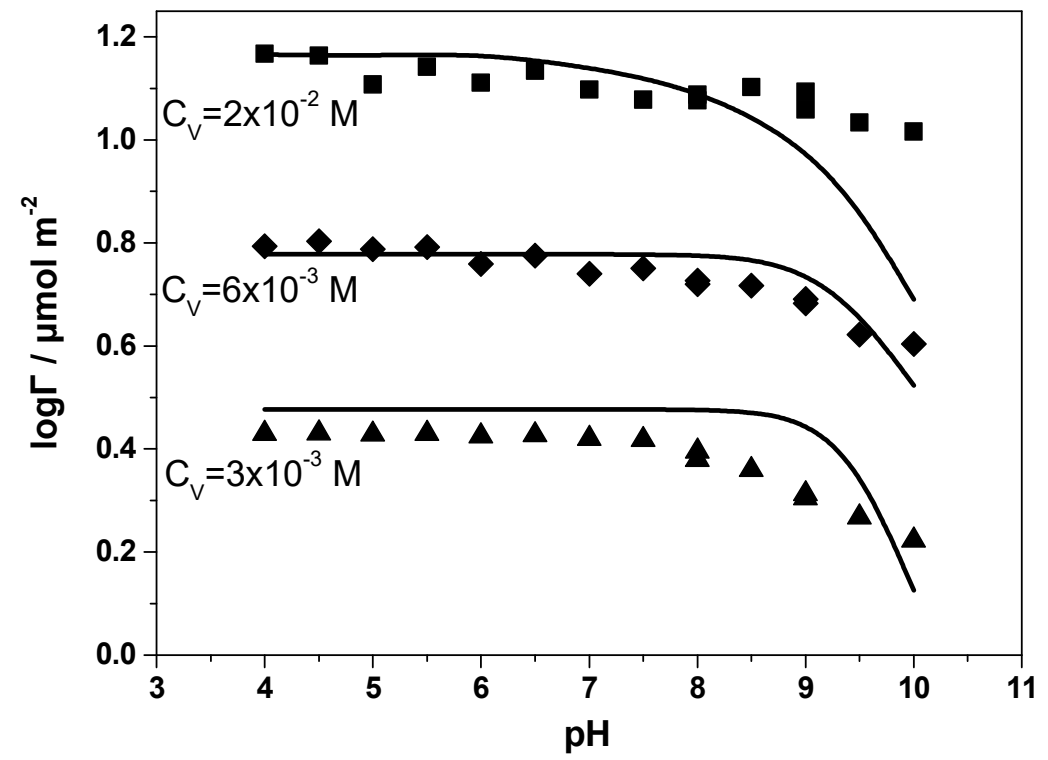

Figure 6. Adsorption edges of $\mathrm{V}(\mathrm{V})$ on titania, at three different $\mathrm{V}$ concentrations (points represent experimental data, whereas solid lines correspond to calculated (model) curves).

This fit was achieved by considering Equilibrium (4), in addition to (2) and (3), which were adopted previously for the deposition of the monomers.

$$
2 \mathrm{TiO}^{-0.35}+4 \mathrm{H}^{+}+\mathrm{V}_{4} \mathrm{O}_{12}^{4-} \stackrel{\mathrm{K}_{\mathrm{T} 3}}{\leftrightarrow}(\mathrm{TiO})_{2} \mathrm{~V}_{4} \mathrm{O}_{10}-0.7+2 \mathrm{H}_{2} \mathrm{O}
$$

According to this equilibrium, the deposition of vanadates on the titania surface takes place via the formation of a disubstituted inner sphere complex between two terminal hydroxyls of the titania surface and one quadramer ion. The structure of this complex on 
the anatase $\left(\begin{array}{lll}1 & 0 & 1\end{array}\right)$ crystal termination, one of the two majority crystal faces of anatase, is illustrated in Figure 7. A similar picture may be obtained by considering the other majority crystal termination of the anatase $\left(\begin{array}{lll}1 & 0 & 0\end{array}\right)$. It should be mentioned that according to the simulation results, the contribution of the other vanadates in the deposition of $\mathrm{V}$ on the titania surface is negligible. A last observation concerning the deposition is that according to Figure 6, vanadates are strongly adsorbed on the titania surface even at $\mathrm{pH}$ values where the surface is negatively charged. It is noteworthy that up to $\mathrm{pH}=8$, there is no $\mathrm{pH}$ dependency of the extent of deposition and such a lack of dependency is extended up to $\mathrm{pH}=10$ at a high total V concentration. This is in full agreement with the kinetic results, which pointed out a strong chemical affinity between titanium oxide and vanadates. This strong interaction leads to vanadia/titania catalysts with high dispersion of the vanadia phase and stable bi-dimensional vanadia structures. The latter will be also verified below by a detailed Raman spectroscopy study.

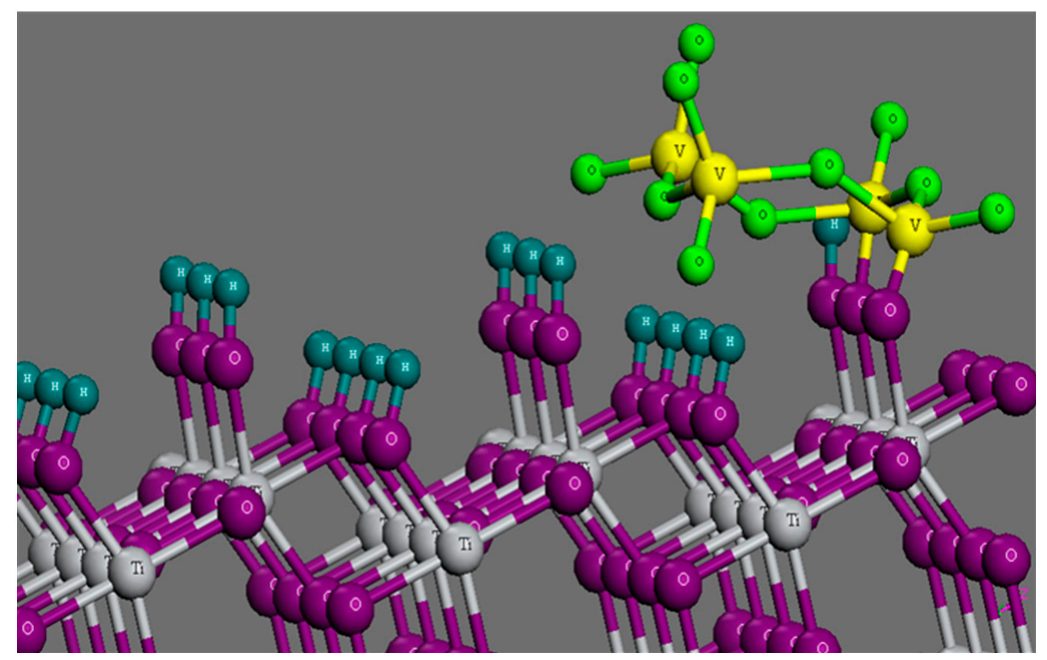

Figure 7. Local structure of the deposited V quadramers on the $\left(\begin{array}{lll}1 & 0 & 1\end{array}\right)$ crystal termination of anatase.

\subsection{Determination of the Interfacial Speciation of Vanadates Adsorbed on Titania Surface}

The successful fitting of the model curves to the experimental data by means of the deposition model (Figures 4 and 6) allowed the calculation of the values of the formation constants, $K_{T 1}, K_{T 2}$, and $K_{T 3}$, of the deposited monomers and quadramers (see Equilibria (2)-(4) and Table A1). This allows us to calculate the interfacial speciation for any value of the main impregnation parameters, namely for any value of $\mathrm{pH}$ and $\mathrm{V}(\mathrm{V})$ solution concentration. Thus, the knowledge of the interfacial speciation is the key for depositing not only the desired amount of the total $\mathrm{V}$ on the titania surface but, in addition, the desired relative amounts of the $\mathrm{V}(\mathrm{V})$ oxo-species. Therefore, it is a very effective tool for obtaining a thorough control of the impregnation step and performing the catalyst synthesis on the basis of a molecular approach. In order to render this speciation more useful from the standpoint of catalyst synthesis, we have expressed it as the percentage of the $\mathrm{V}(\mathrm{V})$ deposited as a certain V(V) oxo-species. In Figure 8, the interfacial speciation of V(V) on titania, over the entire $\mathrm{pH}$ range studied, is illustrated as an example. 


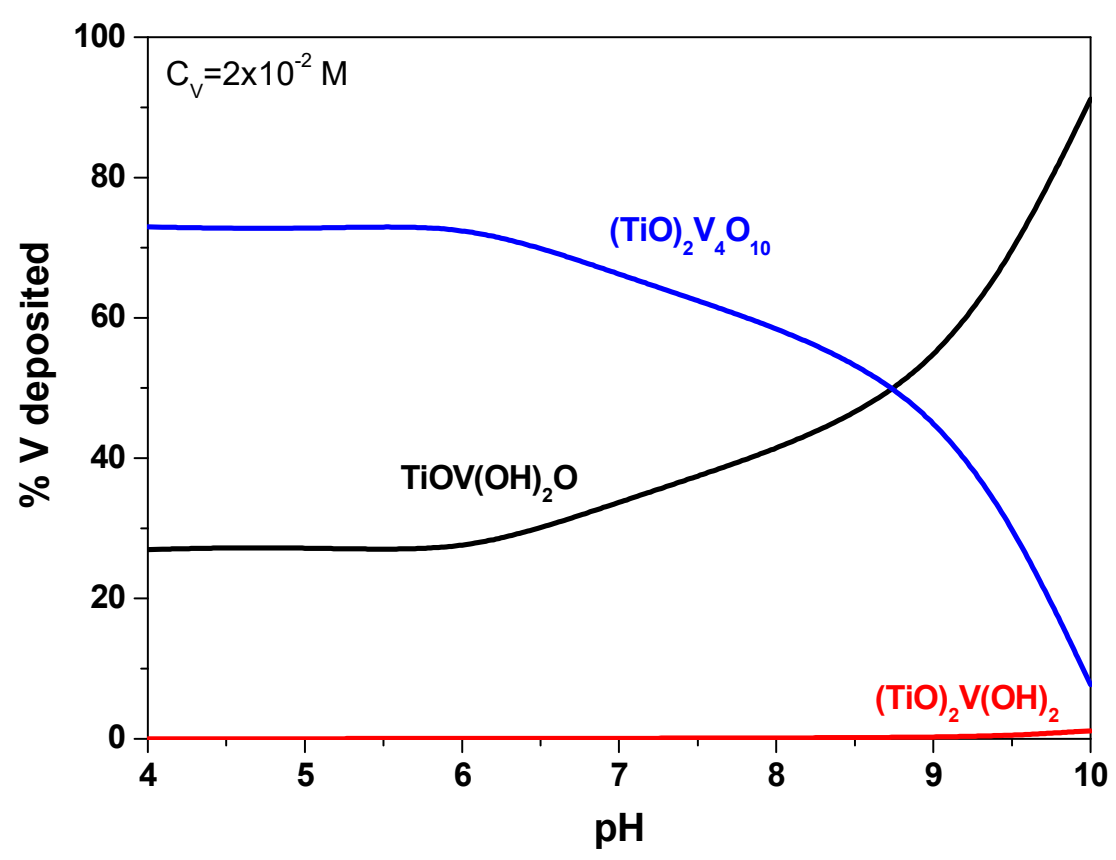

Figure 8. Variation of the percentage of $\mathrm{V}$ deposited as a specific species with the $\mathrm{pH}$ of the impregnating solution. The various deposited $\mathrm{V}(\mathrm{V})$ oxo-species are indicated.

It can be previewed that at very high $\mathrm{pH}$ values (>10), vanadium is deposited on the titania surface exclusively as monomers. Amongst the two monomers, the monosubstituted inner sphere complex $\mathrm{TiOV}(\mathrm{OH})_{2} \mathrm{O}$ is by far the prevailing species. As the $\mathrm{pH}$ decreases, the contribution of quadramers on the deposition of $\mathrm{V}(\mathrm{V})$ on titania becomes more and more significant. At a $\mathrm{pH}$ value $\approx 8.5$, half of the deposited $\mathrm{V}$ is in the form of monomers, while the other half is in the form of quadramers. At $\mathrm{pH}$ values lower than 6 , quadramers are the prevailing species containing $\approx 70 \%$ of the deposited vanadium. A comparison of Figure 8 with Figure $2 \mathrm{f}$ shows that the titania surface exhibits a preference for adsorbing monomers. In the intermediate $\mathrm{pH}$ region (6-8), Figure $2 \mathrm{f}$ shows that $\mathrm{V}$ is mainly in the form of quadramers in the solution. However, Figure 8 shows that at the same $\mathrm{pH}$ region, a significant portion of the deposited $\mathrm{V}$ is in the form of monomers. Moreover, at low $\mathrm{pH}$ values $(<6)$, Figure $2 \mathrm{f}$ shows that the predominant species in the solution are the decamers, whereas at the interface (Figure 8), V can be found mainly in the form of quadramers and monomers. The absence of decamers at the interface (although predominant in the solution) will be further examined and verified by laser Raman Spectroscopy. It should be mentioned that the preferential adsorption of monomeric species on titania in a wide $\mathrm{pH}$ range has also been observed in the deposition of other oxoanions of transition metals, such as tungstates [53], molybdates [49], and chromates [50].

\subsection{Raman Spectroscopy}

\subsubsection{Solution Speciation of Vanadates}

As discussed above, the oxovanadate species possibly formed in aqueous solutions include $\mathrm{HVO}_{4}{ }^{2-}, \mathrm{H}_{2} \mathrm{VO}_{4}{ }^{-}, \mathrm{H}_{2} \mathrm{~V}_{2} \mathrm{O}_{7}{ }^{2-}, \mathrm{V}_{4} \mathrm{O}_{12}{ }^{4-}, \mathrm{V}_{5} \mathrm{O}_{15}{ }^{5-}, \mathrm{HV}_{10} \mathrm{O}_{28}{ }^{5-}$, and $\mathrm{NaHV}_{10} \mathrm{O}_{28}{ }^{4-}$. Considering the above species with their respective formation constants, the solution speciation of the oxo- $\mathrm{V}(\mathrm{V})$ species was determined for various initial concentrations of $\mathrm{V}(\mathrm{V}), \mathrm{C}_{\mathrm{V}(\mathrm{V}) \text { total, }}$ in the $\mathrm{pH}$ range 10-4 (vide ante, Section 2.1, Figure 2). Figure 2e, $\mathrm{f}$ shows the pertinent results for $\mathrm{C}_{\mathrm{V}(\mathrm{V}) \text { total }}=0.02 \mathrm{M}$, which is of direct relevance to the conditions used for the equilibrium deposition of the vanadate species for preparing the samples studied by Raman spectroscopy. Briefly, the model results show that for $\mathrm{pH}=10$, the monomeric tetrahedral vanadate in protonated $\mathrm{HVO}_{4}{ }^{2-}$ and $/$ or $\mathrm{H}_{2} \mathrm{VO}_{4}{ }^{-}$(Figure 1a) form is almost exclusively present, whilst for $\mathrm{pH}=9$, a significant portion of vanadium occurs in the form of the tetrameric $\mathrm{V}_{4} \mathrm{O}_{12}{ }^{4-}$ species (Figure $1 \mathrm{~b}$ ) with di-oxo $\mathrm{O}=\mathrm{V}=\mathrm{O}$ termination 
configuration and fourfold coordination for each $\mathrm{V}$ atom. Species $\mathrm{V}_{4} \mathrm{O}_{12}{ }^{4-}$ prevails in the $\mathrm{pH}$ region 9-6.5, whereas for $\mathrm{pH} \leq 6$, the decavanadate polymeric species $\mathrm{HV}_{10} \mathrm{O}_{28}{ }^{5-}$ and $\mathrm{NaHV}_{10} \mathrm{O}_{28}{ }^{4-}$ gradually prevail and become predominant for $\mathrm{pH}=5-4$. The $\mathrm{V}_{10} \mathrm{O}_{28}{ }^{6-}$ anion consists of corner sharing $\mathrm{VO}_{5}$ and $\mathrm{VO}_{6}$ units and possesses eight terminal $\mathrm{O}$ atoms in mono-oxo $\mathrm{V}=\mathrm{O}$ termination configurations. Two of the $\mathrm{VO}_{6}$ units do not contain terminal $\mathrm{O}$ atoms (Figure 1c).

The tetrahedral $\left(T_{d}\right) \mathrm{VO}_{4}{ }^{3-}$ ion has four vibrational modes that span the following irreducible representation:

$$
\Gamma_{v i b}=A_{1}\left(v_{1}\right)+E\left(v_{2}\right)+2 F_{2}\left(v_{3}+v_{4}\right) .
$$

Only the $F_{2}$ modes are IR allowed, whereas all modes are active in the Raman spectrum. Based on the usual weak-couplings approximation, modes $v_{1}$ and $v_{3}$ are stretchings and modes $v_{2}$ and $v_{4}$ are bendings. Typical wavenumbers for the free ion in aqueous solutions are reported as follows [67]: $v_{1}\left(A_{1}\right) \approx 826 \mathrm{~cm}^{-1}, v_{2}(E) \approx 336 \mathrm{~cm}^{-1}, v_{3}\left(F_{2}\right) \approx 804 \mathrm{~cm}^{-1}$, and $v_{4}\left(F_{2}\right) \approx 336 \mathrm{~cm}^{-1}$. However, protonation and interionic interactions are expected to perturb the bond strengths and shift the observed modes.

Figure 9 shows the Raman spectra obtained for the $\mathrm{V}(\mathrm{V})$ precursor solutions with initial concentration $\mathrm{C}_{\mathrm{V}(\mathrm{V}) \text { total }}=0.02 \mathrm{M}$ and $\mathrm{pH}$ in the range $10-4$. The spectra can be fully interpreted by following the solution speciation previewed by the model (Figure 2e,f) and the pertinent literature. Hence, at $\mathrm{pH}=10$, the displayed stretching region exhibits a broad band centered at $868 \mathrm{~cm}^{-1}$ (possessing also a low wavenumber weak component) that represents the symmetric stretching of the monomeric $\mathrm{VO}_{4}$ units of the $\mathrm{HVO}_{4}{ }^{2-}$ $\left(\mathrm{HOVO}_{3}{ }^{2-}\right)$ and $\mathrm{H}_{2} \mathrm{VO}_{4}{ }^{-}\left[(\mathrm{HO})_{2} \mathrm{VO}_{2}{ }^{-}\right]$species. The blue shift of the $868 \mathrm{~cm}^{-1}$ compared to the indicative $826 \mathrm{~cm}^{-1}$ value reported for the free $\mathrm{VO}_{4}{ }^{3-}$ ion is attributed to strengthening of the terminal $\mathrm{V}-\mathrm{O}$ bonds resulting from the distancing of the protonated $\mathrm{O}$ atoms of the $\mathrm{V}-\mathrm{OH}$ terminations. The respective antisymmetric mode is obscured under the low frequency wing of the $868 \mathrm{~cm}^{-1}$ band. At $\mathrm{pH}=9$ (spectrum Figure $9 \mathrm{~b}$ ), the $868 \mathrm{~cm}^{-1}$ band due to $\mathrm{VO}_{4}$ is diminished, and a band at $946 \mathrm{~cm}^{-1}$ assigned to the $\mathrm{V}_{4} \mathrm{O}_{12}{ }^{4-}$ ion emerges and prevails, as suggested also by the speciation previewed by the theoretical model (Figure 2e,f). In particular, Figure $2 \mathrm{f}$ that shows the model predicted speciation expressed in terms of $\% \mathrm{~V}$ is more appropriate for following the relative intensities of the bands in the Raman spectra shown in Figure 9 because it reflects the relative number of V-O vibrators (scatterers) contributing to the intensity of each observed Raman band. The structure of the $\mathrm{V}_{4} \mathrm{O}_{12}{ }^{4-}$ tetramer ion is characterized by the di-oxo $\mathrm{O}=\mathrm{V}=\mathrm{O}$ termination configuration and tetrahedral coordination for each $\mathrm{V}$ atom, which is similar to the respective structural characteristics of the metavanadate chain, $\left(\mathrm{VO}_{3}\right)_{\mathrm{n}}{ }^{\mathrm{n}-}$. The observed $946 \mathrm{~cm}^{-1}$ band position agrees with the $936 \mathrm{~cm}^{-1}$ observed for molten $\mathrm{NaVO}_{3}$ [64] and is assigned to the symmetric stretching, $v_{s}$, of the di-oxo $\mathrm{V}(=\mathrm{O})_{2}$ unit. The antisymmetric counterpart mode, $v_{a s}$, is obscured by the low-frequency wing of the symmetric mode, thereby resulting in an asymmetric shape for the $946 \mathrm{~cm}^{-1}$ band, which is much clearer at $\mathrm{pH}=8$ (Figure 9c), where the additional display of the Raman spectrum obtained with the $\mathrm{VH}$ configuration allows the exclusive presence of the $v_{a s}$ mode at $\approx 915 \mathrm{~cm}^{-1}$. The behavior is similar to the Raman spectra obtained for molten $\mathrm{NaVO}_{3}$ [68].

At $\mathrm{pH}=8$ and 7, in accordance with the model-predicted speciation of Figure 2f, the Raman spectra in Figure 9c,d show the exclusive presence of species $\mathrm{V}_{4} \mathrm{O}_{12}{ }^{4-}$, represented by the $v_{s} / v_{a s}$ convolution. At $\mathrm{pH}=6$ (Figure $9 \mathrm{e}$ ), the $946 \mathrm{~cm}^{-1}$ band intensity is lowered abruptly due to the decrease of $\mathrm{V}_{4} \mathrm{O}_{12}{ }^{4-}$ presence and the prevalence of ${ }^{\prime} \mathrm{V}_{10} \mathrm{O}_{28}$ ' (i.e., species $\mathrm{HV}_{10} \mathrm{O}_{28}{ }^{5-}$ and $\mathrm{NaHV}_{10} \mathrm{O}_{28}{ }^{4-}$ ) represented by three bands at $995-1000 \mathrm{~cm}^{-1}$, $\approx 967$ and $\approx 835 \mathrm{~cm}^{-1}$ [69]. The $967 \mathrm{~cm}^{-1}$ band's presence is less prominent at $\mathrm{pH}=6$ due to the overlap with the remainder of the $946 \mathrm{~cm}^{-1}$ band. A slight blue shift of the main $995 \mathrm{~cm}^{-1}$ band on going from $\mathrm{pH}=6$ to $\mathrm{pH}=4$ is justifiable due to perturbations caused by protons and $\mathrm{Na}^{+}$ions. 


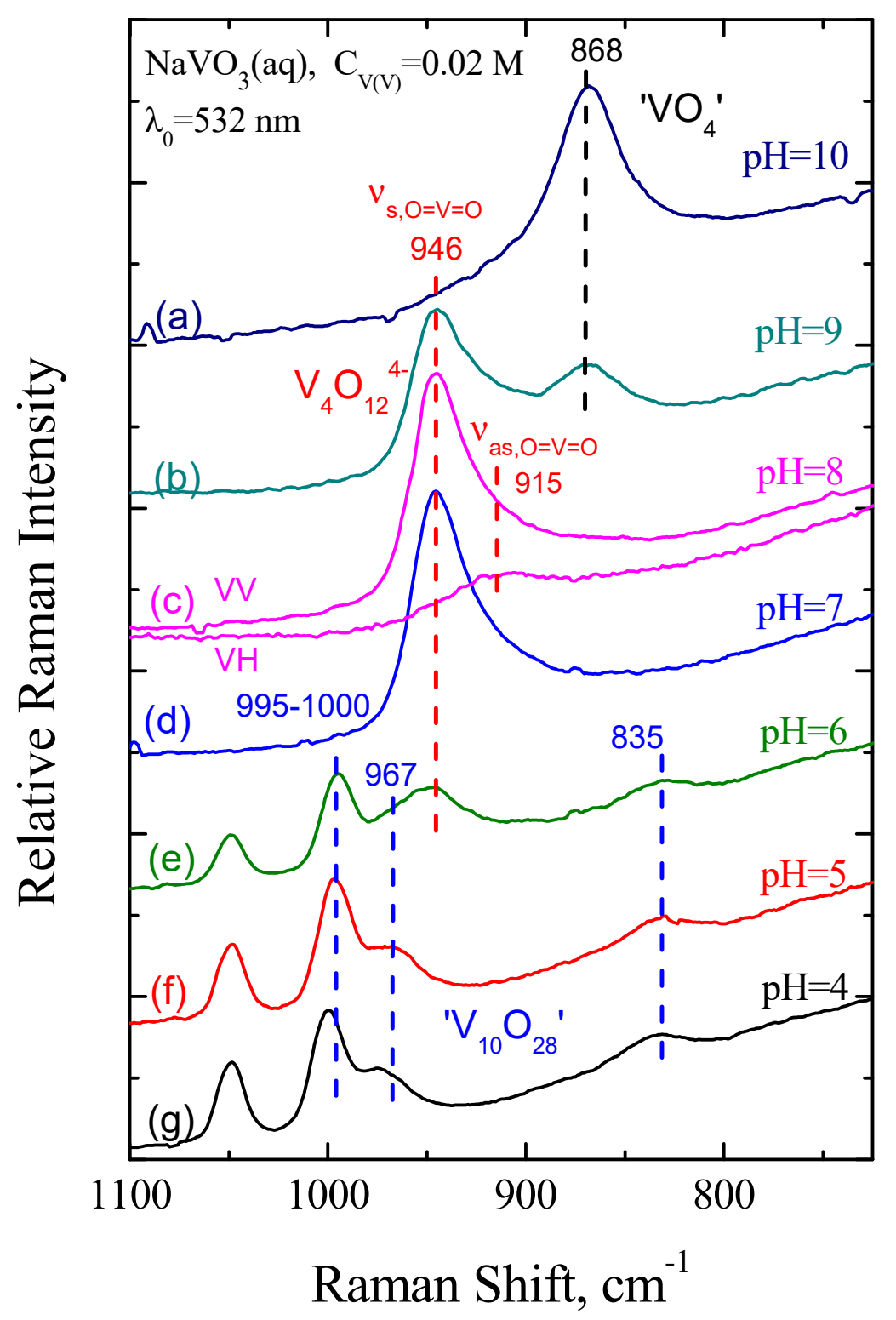

Figure 9. Raman spectra of $\mathrm{NaVO}_{3}$ solutions with initial concentration $\mathrm{C}_{\mathrm{V}(\mathrm{V}) \text {, total }}=2.0 \times 10^{-2} \mathrm{M}$ and ionic strength $\mathrm{I}=0.1 \mathrm{M} \mathrm{NaNO}_{3}$. ' $\mathrm{VO}_{4}{ }^{\prime}$ denotes species $\mathrm{HVO}_{4}{ }^{2-}$ and $\mathrm{H}_{2} \mathrm{VO}_{4}{ }^{-} ;{ }^{\prime} \mathrm{V}_{10} \mathrm{O}_{28}$ ' denotes species $\mathrm{HV}_{10} \mathrm{O}_{28}{ }^{5-}$ and $\mathrm{NaHV}_{10} \mathrm{O}_{28}{ }^{4-}$ (laser wavelength, $\lambda_{0}=532 \mathrm{~nm}$; laser power, $50 \mathrm{~mW}$ ).

Hence, the model predictions for the speciation of $\mathrm{V}(\mathrm{V})$ species in the precursor solutions is fully justified by the Raman spectra obtained for the aqueous $\mathrm{NaVO}_{3}$ solutions with initial concentration of $\mathrm{C}_{\mathrm{V}(\mathrm{V}) \text { total }}=0.02 \mathrm{M}$ and $\mathrm{pH}$ in the range 10-4.

2.5.2. Raman Spectra of Wet $\mathrm{H}_{K} \mathrm{~V}_{X} \mathrm{O}_{Y}{ }^{\mathrm{Z}-} / \mathrm{TiO}_{2}$ Pastes. Verification of the Interfacial Speciation of Vanadates by In Situ Raman Spectroscopy

Recording of the Raman spectra for the wet $\mathrm{H}_{\mathrm{K}} \mathrm{V}_{\mathrm{X}} \mathrm{O}_{\mathrm{Y}} \mathrm{Z}^{-} / \mathrm{TiO}_{2}$ pastes took place right after the equilibrium deposition and filtration (i.e., before the drying and calcination procedures) at $25^{\circ} \mathrm{C}$ under flowing $\mathrm{O}_{2}(\mathrm{~g})$ using the in situ optical Raman cell described in Section 3.6 (Materials and Methods section). Figure 10 shows the pertinent spectra of the wet pastes obtained after equilibrium deposition of oxo- $\mathrm{V}(\mathrm{V})$ species on $\mathrm{TiO}_{2}(\mathrm{P} 25)$ from precursor solutions with initial concentration of $\mathrm{C}_{\mathrm{V}(\mathrm{V}) \text { total }}=0.02 \mathrm{M}$ at $\mathrm{pH}$ values of $10,9,8,7,6,5$, and 4 and subsequent filtration. It should be pointed out that the Raman spectra of the $\mathrm{H}_{\mathrm{K}} \mathrm{V}_{\mathrm{X}} \mathrm{O}_{\mathrm{Y}}{ }^{\mathrm{Z}-} / \mathrm{TiO}_{2}$ wet pastes will be discussed with reference to the oxo- $\mathrm{V}(\mathrm{V})$ 
species deposited at the interface, and the species identification will be compared to the interfacial speciation of the oxo- $\mathrm{V}(\mathrm{V})$ species calculated based on the above described model (Figure 8).

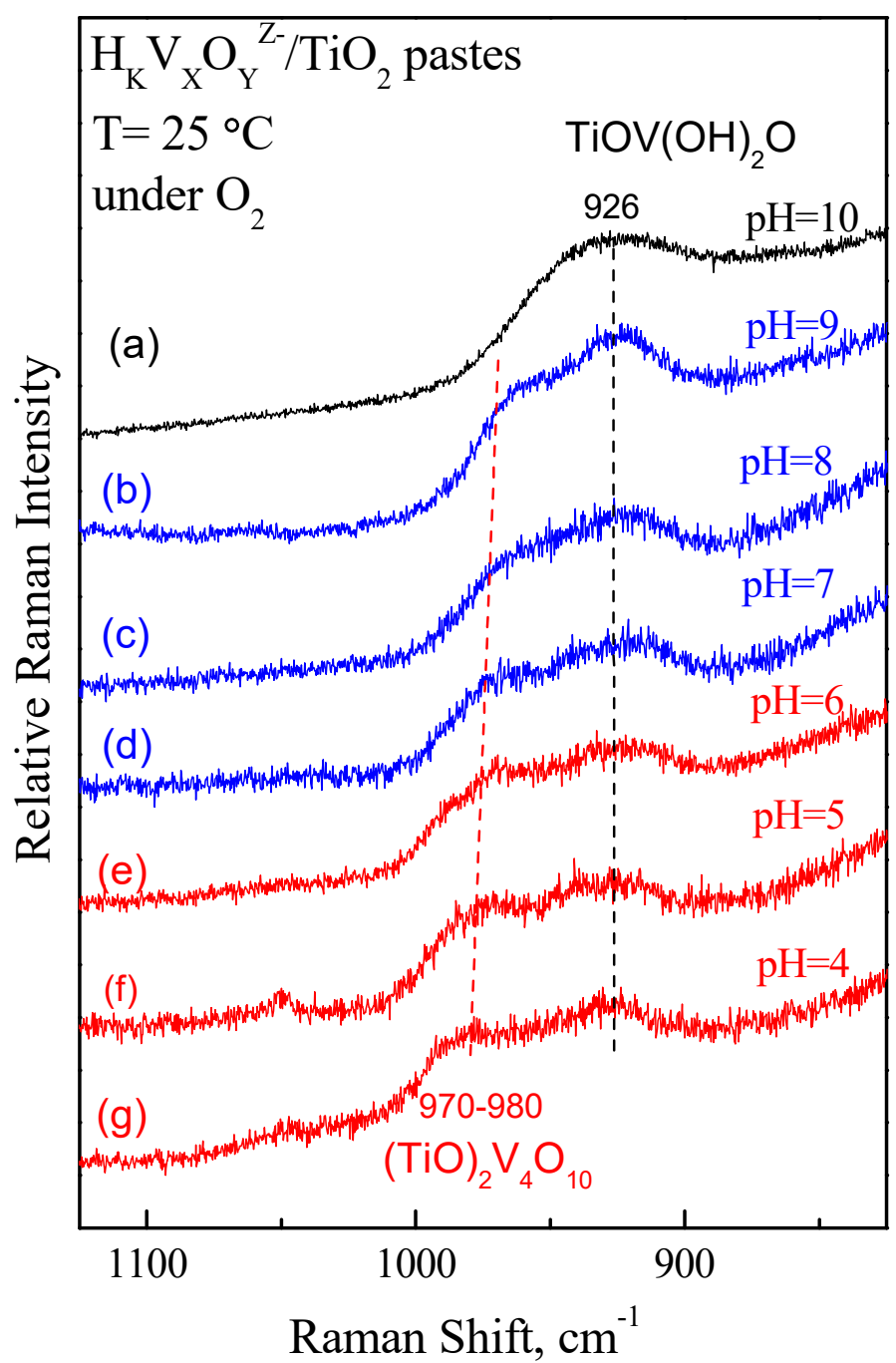

Figure 10. In situ Raman spectra obtained under flowing $\mathrm{O}_{2}(\mathrm{~g})$ for the wet pastes $\mathrm{H}_{K} \mathrm{~V}_{X} \mathrm{O}_{Y}{ }^{\mathrm{Z}-} / \mathrm{TiO}_{2}$ prepared by the equilibrium deposition filtration (EDF) method. The indicated $\mathrm{pH}$ values pertain to the respective impregnating solutions with $\mathrm{C}_{\mathrm{V}(\mathrm{V}) \text { total }}=0.02 \mathrm{M}$ (laser wavelength, $\lambda_{0}=491.5 \mathrm{~nm}$; laser power: $15 \mathrm{~mW}$; spectral slit width: $7 \mathrm{~cm}^{-1}$ ). (a) $\mathrm{pH}=10$; (b) $\mathrm{pH}=9$; (c) $\mathrm{pH}=8$; (d) $\mathrm{pH}=7$; (e) $\mathrm{pH}=6$; (f) $\mathrm{pH}=5 ;$ (g) $\mathrm{pH}=4$.

Figure 10 is confined in the $\mathrm{V}-\mathrm{O}$ stretching region. Strong bands due to the $\mathrm{TiO}_{2}(\mathrm{P} 25)$ carrier prevail below $825 \mathrm{~cm}^{-1}$. At $\mathrm{pH}=10$ (spectrum Figure 10a), one single broad band is seen at $926 \mathrm{~cm}^{-1}$ and is assigned to the symmetric stretching $\mathrm{VO}_{4}$ vibration of the monoand disubstituted inner sphere $\mathrm{H}_{2} \mathrm{VO}_{4}{ }^{-}$deposited complexes illustrated in Figure 5. The theoretical model for the interfacial speciation (Figure 8) predicts the exclusive presence of $\mathrm{H}_{2} \mathrm{VO}_{4}{ }^{-}$species for $\mathrm{pH}=10$ and particularly the large prevalence of the monosubstituted Ti-O- $-\mathrm{V}(\mathrm{OH})_{2} \mathrm{O}$ configuration. The tetrahedral $\mathrm{VO}_{4}$ symmetry is disturbed and lowered due to the distancing of the anchored $\mathrm{O}$ atoms that tend to shorten the terminal $\mathrm{V}-\mathrm{O}$ and $\mathrm{V}-\mathrm{O}(\mathrm{H})$ bonds, thereby justifying the $926 \mathrm{~cm}^{-1}$ band position, compared to the $828 \mathrm{~cm}^{-1}$ value for the free $\mathrm{VO}_{4}{ }^{3-}$ ion and to the $868 \mathrm{~cm}^{-1}$ value for the protonated $\mathrm{HVO}_{4}{ }^{2-}$ and $\mathrm{H}_{2} \mathrm{VO}_{4}{ }^{-}$ions in the precursor solutions (Figure 9a). In addition, a distribution of bond 
strengths amongst the terminal sites is caused due to the protonation of some of the $\mathrm{O}$ atoms, thereby accounting for the broadness of the $926 \mathrm{~cm}^{-1}$ band.

In the Raman spectrum obtained for the $\mathrm{H}_{\mathrm{K}} \mathrm{V}_{X} \mathrm{O}_{Y}{ }^{\mathrm{Z}-} / \mathrm{TiO}_{2}$ paste prepared at $\mathrm{pH}=9$ (Figure 10b), a new broad band emerges at $\approx 970 \mathrm{~cm}^{-1}$, which according to the model predicted interfacial speciation (Figure 8 ) is assigned to the disubstituted inner sphere complex $\mathrm{Ti}_{2} \mathrm{O}_{2} \mathrm{~V}_{4} \mathrm{O}_{10}$ (Figure 7). The corresponding band for the precursor $\mathrm{V}_{4} \mathrm{O}_{12}{ }^{4-}$ ion in the respective precursor solution was $946 \mathrm{~cm}^{-1}$ (Figure $9 \mathrm{~b}-\mathrm{d}$ ). The $\approx 970 \mathrm{~cm}^{-1}$ band (Figure 10b) gradually gains intensity on going from $\mathrm{pH}=9$ to $\mathrm{pH}=7$ at the expense of the $926 \mathrm{~cm}^{-1}$, and no further changes can be discerned in the Raman spectra obtained for the pastes prepared at $\mathrm{pH}=6-4$, which is in full agreement with the theoretically predicted interfacial speciation (Figure 8). Now, the $\approx 970 \mathrm{~cm}^{-1}$ band (tending to undergo a blue shift with the decreasing $\mathrm{pH}$ of the synthesis procedure) appears to have several components in agreement with the structural configuration of the disubstituted inner sphere complex shown in Figure 7, in which terminal mono-oxo $\mathrm{VO}$ as well as terminal dioxo $\mathrm{VO}_{2}$ sites exist, thereby justifying the band broadness. The mono-oxo sites contribute to the high wavenumber side of the band, whilst the di-oxo sites create a peak mass at the low wavenumber side of the $970-980 \mathrm{~cm}^{-1}$ band.

It is noteworthy that both the theoretically predicted and the experimentally verified solution speciation (Figure 2e,f and Figure 9) show either a significant presence (at $\mathrm{pH}=6$ ) or a prevalence (at $\mathrm{pH}=5-4$ ) of polymeric decavanadate species (i.e., $\mathrm{HV}_{10} \mathrm{O}_{28}{ }^{5-}$ and $\mathrm{NaHV}_{10} \mathrm{O}_{28}{ }^{4-}$ ) in the precursor solutions. However, neither the theoretically predicted interfacial speciation nor the Raman spectra of the wet $\mathrm{H}_{\mathrm{K}} \mathrm{V}_{X} \mathrm{O}_{Y}{ }^{\mathrm{Z}}-/ \mathrm{TiO}_{2}$ pastes show evidence for such species deposition in the respective $\mathrm{pH}$ region. Hence, the interfacial speciation of the deposited species is largely different to the respective solution speciation of the precursor species. The apparent selectivity of the surface for "rejecting" the decavanadate ions can be due to a number of reasons: (a) the negatively charged surface repels the polymeric decavanadate anions that possess a high negative charge; (b) the stereochemical obstruction for the large decavanadate ions approach; (c) the preference for the deposition of species by means of coordinative bonds as opposed to electrostatic retainment of the polymeric species. This behavior is indicative of the EDF method's ability for designing the configurational characteristics of the deposited vanadate species at the molecular level.

\subsubsection{Temperature-Dependent Evolution of the Molecular Structure of Vanadates Deposited on Titania}

Figure 11 shows the temperature-dependent evolution of in situ Raman spectra obtained from 25 to $430{ }^{\circ} \mathrm{C}$ for two representative $\mathrm{H}_{\mathrm{K}} \mathrm{V}_{\mathrm{X}} \mathrm{O}_{Y}{ }^{\mathrm{Z}-} / \mathrm{TiO}_{2}$ pastes, namely the ones prepared at the two extrema of the $\mathrm{pH}$ range used for the synthesis, i.e., at $\mathrm{pH}=10$ (Figure 11a) and $\mathrm{pH}=4$ (Figure 11b).

The temperature evolution of the Raman spectra shows that from the initial (at $25^{\circ} \mathrm{C}$ ) prevalent configurations (i.e., the monomeric monosubstituted umbrella-like Ti-O$\mathrm{V}(\mathrm{OH})_{2} \mathrm{O}$ species exclusively present on $\mathrm{H}_{K} \mathrm{~V}_{\mathrm{X}} \mathrm{O}_{Y} \mathrm{Z}^{-} /\left.\mathrm{TiO}_{2}\right|_{\mathrm{pH}}=10$ and the tetrameric disubstituted (Ti-O) ${ }_{2} \mathrm{~V}_{4} \mathrm{O}_{10}$ in co-existence with Ti-O- $\mathrm{V}(\mathrm{OH})_{2} \mathrm{O}$ on $\mathrm{H}_{K} \mathrm{~V}_{\mathrm{X}} \mathrm{O}_{Y}{ }^{Z-} /\left.\mathrm{TiO}_{2}\right|_{\mathrm{pH}=4}$ ) until the final $\left(\mathrm{VO}_{\mathrm{x}}\right)_{\mathrm{n}}$ configurations prevailing in the calcined samples (blue traces in Figure 11a,b), a gradual transformation resulting in a number of intermediate structural modifications takes place. Initially, up to the typical temperature limit of drying (i.e., $\left.120^{\circ} \mathrm{C}\right), \mathrm{H}_{2} \mathrm{O}$ molecules are detached by a combination of hydroxyls and hydrogen atoms, thereby creating vacant bonding sites on the carrier and "opportunities" for a surface diffusion, spillover, and subsequent anchoring. Hence, the $926 \mathrm{~cm}^{-1}$ band is gradually diminished in both samples, and its main component undergoes a blue shift due to strengthening of the $\mathrm{V}-\mathrm{O}$ bond in view of the deprotonation of the $\mathrm{Ti}-\mathrm{O}-\mathrm{V}(\mathrm{OH})_{2} \mathrm{O}$ species that initially transforms to Ti-O- $\mathrm{V}(\mathrm{OH}) \mathrm{O}_{2}$ and subsequently to Ti-O- $\mathrm{VO}_{3}$. At intermediate temperatures $\left(120<\mathrm{T} \leq 250^{\circ} \mathrm{C}\right)$, the Raman spectra are suggestive of a di-oxo $\mathrm{O}=\mathrm{V}=\mathrm{O}$ termination configuration for the prevailing species (symmetric $v_{s, \mathrm{O}}=\mathrm{V}=\mathrm{O}$ at $955-970 \mathrm{~cm}^{-1}$ ), 
whilst at higher temperatures $\left(\mathrm{T}>250^{\circ} \mathrm{C}\right)$, the emergence of the characteristic $\mathrm{V}=\mathrm{O}$ bond above $1000 \mathrm{~cm}^{-1}$ takes place for both samples (Figure 11a,b). Gradual transformations due to progressive anchoring and association to neighboring sites with increasing temperature occur also for the disubstituted ( $\mathrm{Ti}-\mathrm{O})_{2} \mathrm{~V}_{4} \mathrm{O}_{10}$ species on $\mathrm{H}_{K} \mathrm{~V}_{X} \mathrm{O}_{Y}{ }^{Z-} /\left.\mathrm{TiO}_{2}\right|_{\mathrm{pH}=4}$ (Figure 11b), resulting in lowering of the $980 \mathrm{~cm}^{-1}$ and gradual emergence of the $1020 \mathrm{~cm}^{-1}$ $\mathrm{V}=\mathrm{O}$ band. The $\mathrm{V}-\mathrm{O}-\mathrm{V}$ bridges existing within the deposited quadramer contribute to the two-dimensional growth of the resulting $\left(\mathrm{VO}_{\mathrm{x}}\right)_{\mathrm{n}}$ domains.

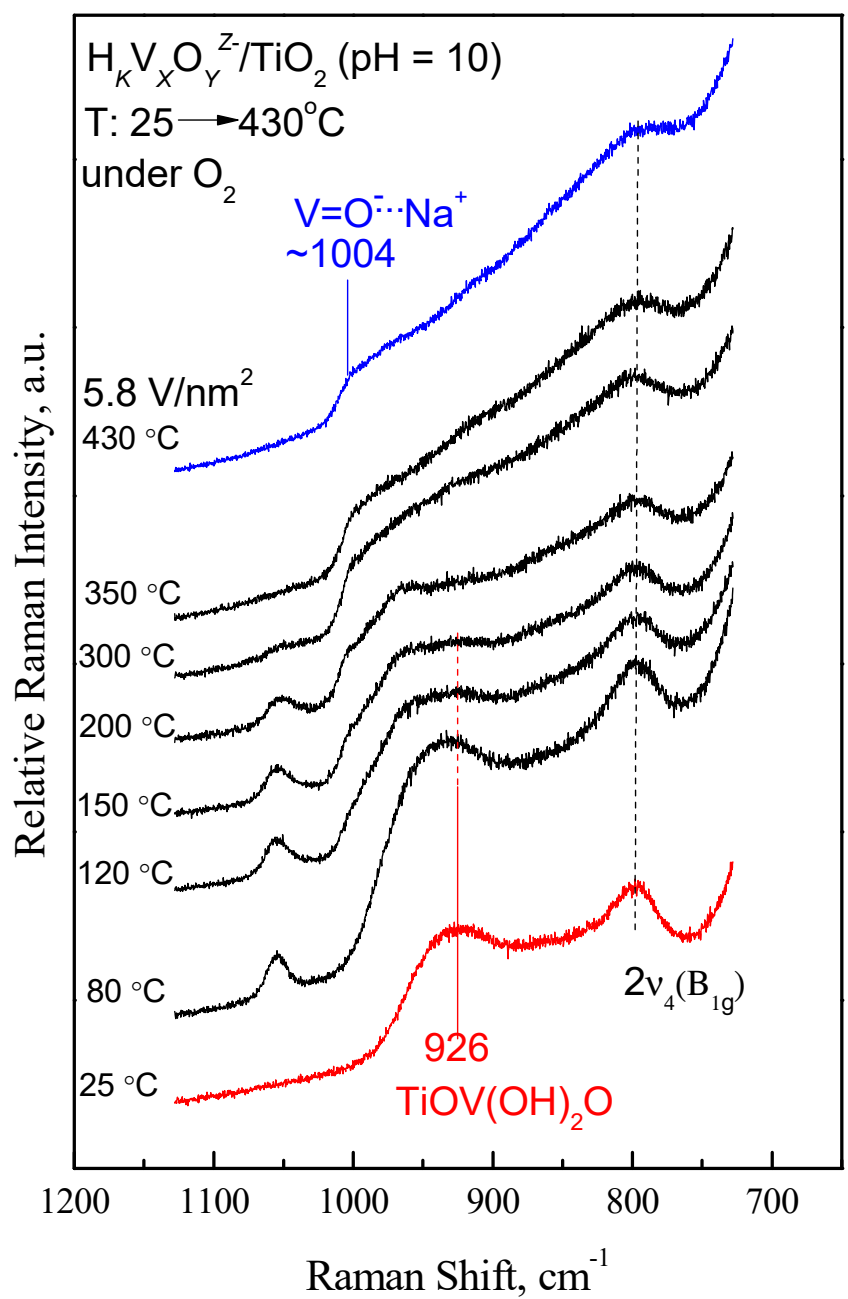

(a)

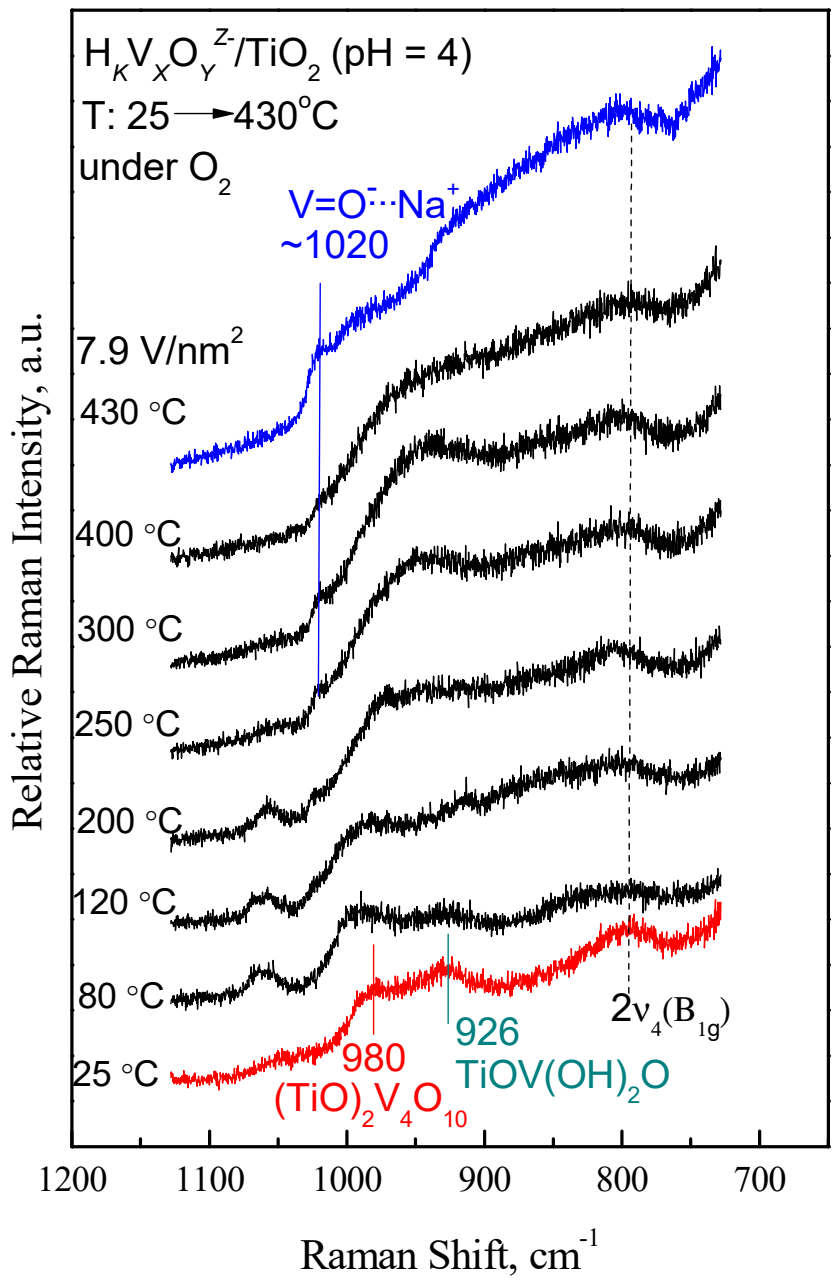

(b)

Figure 11. Temperature evolution snapshots of in situ Raman spectra obtained under flowing $\mathrm{O}_{2}(\mathrm{~g})$ for the wet pastes $\mathrm{H}_{K} \mathrm{~V}_{X} \mathrm{O}_{Y} \mathrm{Z}^{-} / \mathrm{TiO}_{2}$ prepared by the EDF method at (a) $\mathrm{pH}=10 ;(\mathbf{b}) \mathrm{pH}=4$ at temperatures as indicated by each spectrum (laser wavelength, $\lambda_{0}=491.5 \mathrm{~nm}$; laser power: $15 \mathrm{~mW}$; spectral slit width: $7 \mathrm{~cm}^{-1}$ ). The first overtone of the $v_{4}\left(B_{1 \mathrm{~g}}\right)$ anatase mode at $\approx 792 \mathrm{~cm}^{-1}$ is denoted by $2 v_{4}\left(\mathrm{~B}_{1 \mathrm{~g}}\right)$.

The coverages for the finally obtained samples after calcination for $4 \mathrm{~h}$ at $480{ }^{\circ} \mathrm{C}$ under static air correspond to $5.8 \mathrm{~V} / \mathrm{nm}^{2}$ for the sample prepared at $\mathrm{pH}=10$ and to $7.9 \mathrm{~V} / \mathrm{nm}^{2}$ for the counterpart sample prepared at $\mathrm{pH}=4$. Interestingly, a broad peak mass centered at $\approx 930 \mathrm{~cm}^{-1}$ is seen for the sample with the highest $V$ surface density, which is assigned as documented earlier [56,70-73] to $\mathrm{V}-\mathrm{O}-\mathrm{V}$ functionalities, suggestive of polyvanadate species formation at high surface densities.

Notably, the bands due to the $\mathrm{V}=\mathrm{O}$ terminal bonds in the in situ Raman spectra obtained at $430{ }^{\circ} \mathrm{C}$ (Figure 11a,b) are not distinctly discerned, contrary to those reported earlier [56,73], and moreover, their $\approx 1004$ and $1020 \mathrm{~cm}^{-1}$ wavenumbers deviate from 
the 1026-1031 $\mathrm{cm}^{-1}$ usual expected range for terminal mono-oxo $\mathrm{V}=\mathrm{O}$ sites on titania, thereby showing evidence for a perturbation of the $\mathrm{V}=\mathrm{O}$ site that results in $\mathrm{V}=\mathrm{O}$ bond elongation. Indeed, one should take into account that the prepared catalysts are doped with sodium, since the precursor used was $\mathrm{NaVO}_{3}$ and the ionic strength of the precursor solutions was adjusted by $\mathrm{NaNO}_{3}$ solutions. Hence, as shown by Bulushev et al. [74], alkali atoms through an electrostatic $(-\mathrm{O})_{\mathrm{x}} \mathrm{V}=\mathrm{O}^{\mathcal{\delta}-} \ldots \mathrm{Na}^{\delta+}$ interaction cause an elongation of the $\mathrm{V}=\mathrm{O}$ bond, by that means accounting for the downward shift and broadening of the $\mathrm{V}=\mathrm{O}$ band [75]. Periodic density functional theory (DFT) calculations [76] combined also with experimental evidence [77] have shed additional light on the effect of alkali on the perturbation of the $\mathrm{V}=\mathrm{O}$ bond in supported vanadium oxide catalysts.

\section{Materials and Methods}

\subsection{Substances}

Titania (Degussa P25) containing 80\% $w / w$ anatase and 20\% $w / w$ rutile was used as the support in all cases. Its surface composition is $\approx 90 \%$ anatase and only $\approx 10 \%$ rutile. More details about its textural analysis can be found in ref. [49]. $\mathrm{NaNO}_{3}$ dissolved in triply distilled water and $\mathrm{NaVO}_{3}$ were used for the preparation, respectively, of the inert electrolyte and impregnation solutions necessary for the kinetic experiments and the synthesis of the wet vanadia/titania samples for the Raman spectroscopy measurements.

\subsection{Proton-ion Titrations and Adsorption Experiments}

Proton-ion titrations and adsorption experiments data used for the quantitative modeling were drawn from ref. [64], where full experimental details about these experiments can be found.

\subsection{Kinetic Experiments}

First, $40 \mathrm{~mL}$ of $0.1 \mathrm{~N} \mathrm{NaNO}_{3}$ inert electrolyte solution and $2 \mathrm{~g}$ of $\mathrm{TiO}_{2}$ were placed in a double-walled Pyrex thermostable container with a Perspex lid, which is properly shaped so that there are places for the combined $\mathrm{pH}$ measuring electrode, the automatic titration micro-pipeline, and the supply nozzle $\mathrm{N}_{2}$, with which an inert atmosphere is achieved. Then, the suspension was allowed to equilibrate for about $2 \mathrm{~h}$ under continuous stirring and $\mathrm{N}_{2}$ flow, while the temperature was kept constant at $25 \pm 0.1{ }^{\circ} \mathrm{C}$ throughout the experiment. After $2 \mathrm{~h}$, the $\mathrm{pH}$ measuring electrode was placed in the suspension for continuous recording. Then, the appropriate amount of $0.1 \mathrm{M} \mathrm{HNO}_{3}$ standard solution was added so that the initial $\mathrm{pH}$ of the suspension was adjusted to 4 . This was followed by equilibration of the suspension for about $30 \mathrm{~min}$, and then, the necessary $\mathrm{ml}$ of $10^{-2} \mathrm{M}$ vanadium solution was added so that its final concentration in the suspension is equal to $6 \times 10^{-3} \mathrm{M}$. Immediately, titration was started by adding small amounts of standardized $\mathrm{HNO}_{3}$ solution $(0.1 \mathrm{M})$, in order to keep the $\mathrm{pH}$ of the suspension constant at 4 and sampling for the next $2 \mathrm{~h}$. The above procedure was performed for two more initial suspension $\mathrm{pH}$ values, equal to 6.5 and 9. In these cases, a standard $0.1 \mathrm{M} \mathrm{NaOH}$ solution was initially added, in order to adjust the initial suspension $\mathrm{pH}$ to 6.5 and 9 , respectively. The titration was done with the help of an automatic micropipette (Radiometer Copenhagen ABU901 Autoburette), which was equipped with a suitable computer program. In order to determine the amount of vanadium remaining in the suspensions and therefore that deposited on the surface of titania, spectrophotometric analysis of the vanadium in the samples taken was performed.

\subsection{Simulations}

The simulations of the proton-ion titration curves and the adsorption edges were carried out using Visual MINTEQ, which is a computer code for the calculation of chemical equilibria in aqueous media [65]. The simulations were achieved by fitting to the experimental data the corresponding calculated curves, taking into account the mass and the charge balance equations as well as the equilibrium equations for each species being at the 
various planes (or layers) of the interface developed between the titania surface and the impregnation solution containing the vanadates (see Appendix A).

\subsection{Synthesis of Vanadia/Titania Samples}

The equilibrium deposition filtration (EDF) method was used to prepare the samples [41]. $\mathrm{TiO}_{2}$ (Degussa P25) was used as support, while the precursor of the active phase was $\mathrm{NaVO}_{3}$. The ionic strength of the solutions, containing the precursor at the desired concentration $\left(\mathrm{C}_{\mathrm{V}}=2.0 \times 10^{-2} \mathrm{M}\right)$, was adjusted with $0.1 \mathrm{M} \mathrm{NaNO}_{3}$. In various thermostatic vessels (varying in the $\mathrm{pH}$ of the suspension), the oxo-vanadium species were deposited on the $\mathrm{TiO}_{2}$ surface at seven different $\mathrm{pH}$ values $(10,9,8,7,6,5$, and 4), until each system reaches equilibrium. The $\mathrm{pH}$ adjustment/control was done automatically with an autoburette Radiometer Copenhagen ABU901. The filtration procedure was followed to obtain the wet $\mathrm{H}_{\mathrm{K}} \mathrm{V}_{\mathrm{X}} \mathrm{OO}^{\mathrm{Z}}{ }^{\mathrm{-}} / \mathrm{TiO}_{2}$ samples.

\subsection{Raman Spectroscopy}

\subsubsection{Raman Spectra of Precursor Solutions}

Raman spectra of the precursor solutions with initial $\mathrm{V}(\mathrm{V})$ concentration equal to $C_{V(V)}=2.0 \times 10^{-2} \mathrm{M}$ and $\mathrm{pH}$ in the range 4-10 (i.e., $\mathrm{pH}=10,9,8,7,6,5$, and 4) were recorded at room temperature using the linearly polarized $532 \mathrm{~nm}$ line of a diode-pumped $\mathrm{CW}$ laser (excelsior, Specra-Physics) operated at $50 \mathrm{~mW}$. The scattered light was collected at $90^{\circ}$ (horizontal scattering plane), passed through an edge filter for rejecting the elastic scattering, and analyzed by an iHR-320 JY(Horriba) monochromator equipped with a thermoelectrically $-60{ }^{\circ} \mathrm{C}$ cooled CCD detector interfaced with Labspec software. The polarized (VV: vertical polarization of incident laser-vertical analysis of scattered light) as well as the depolarized (VH: vertical polarization of incident laser-horizontal analysis of scattered light) configurations of scattering geometry were employed utilizing a set of Glan and Glan-Thompson polarizers (Hale) with extinction coefficients better than $10^{-6}$ and $10^{-7}$, respectively. Hence, bands pertaining to totally symmetric vibrations could be discerned due to their exclusive presence under the VV configuration. Notably, this could not be achieved in the Raman spectra of wet pastes, owing to the amorphous nature of the pertinent deposited species that results in scrambling of the polarization.

\subsubsection{In situ Raman Spectra of Wet $\mathrm{H}_{\mathrm{K}} \mathrm{V}_{\mathrm{X}} \mathrm{O}_{\mathrm{Y}}{ }^{\mathrm{Z}-} / \mathrm{TiO}_{2}$ Pastes and Calcined Samples}

Figure 12 shows the homemade optical cell assembly used for studying the temperature evolution of the Raman spectra obtained for the $\mathrm{H}_{\mathrm{K}} \mathrm{V}_{\mathrm{X}} \mathrm{O}_{\mathrm{Y}} \mathrm{Z}^{\mathrm{-}} / \mathrm{TiO}_{2}$ wet pastes. The pastes were puttied in the cavity of a " $\mathrm{U}$ "-shaped quartz holder, which is mounted in the vertical position on the optical cell sample holder by means of a gold wire. The incident laser beam is directly focused on the puttied paste (suspended within the U-shaped quartz holder), and hence, with adequate arrangement of the optical geometry, there is no direct illumination of quartz and the sampling is containerless. Moreover, there are no quartz bands within the $\mathrm{V}-\mathrm{O}$ stretching region displayed, the nearest weak quartz band being at $\approx 805 \mathrm{~cm}^{-1}$ [78]. Temperature-dependent snapshots of in situ Raman spectra under flowing $\left(15 \mathrm{~cm}^{3} / \mathrm{min}\right) \mathrm{O}_{2}(\mathrm{~g})$ were recorded by gradual increase of the temperature in the $25-430{ }^{\circ} \mathrm{C}$ range. For recording the Raman spectra of calcined powderous samples, 90-100 mg of sample were pressed in the form of a wafer disc, which was mounted on the sample holder. A cylindrical focusing lens was used for illuminating the samples with the incident laser beam (typically $10-15 \mathrm{~mW}$ on the sample), which was slightly defocused for reducing the irradiance. The cyan $491.5 \mathrm{~nm}$ line of an air-cooled DPSS (Diode Pumped Solid State) Cobolt laser was used as the excitation source. The scattered light was collected at $90^{\circ}$ on a horizontal scattering plane, analyzed with a $0.85 \mathrm{~m}$ Spex 1403 double spectrometer, and detected by a $-20{ }^{\circ} \mathrm{C}$ cooled RCA photomultiplier tube interfaced with a Labspec acquisition software. 


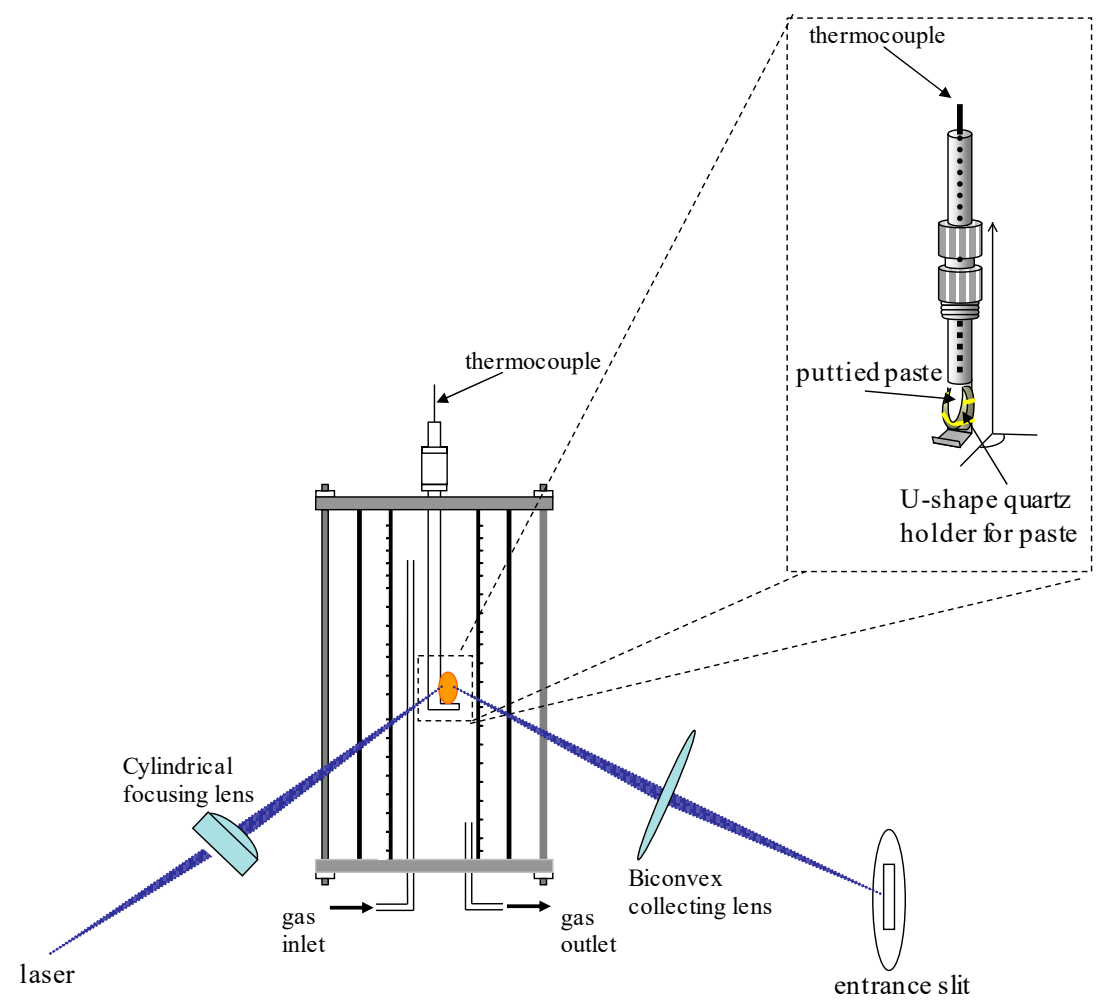

Figure 12. Optical cell for in situ Raman measurements.

\section{Conclusions}

The type of deposition and the speciation of oxo- $\mathrm{V}(\mathrm{V})$ species at the titania/electrolyte precursor solution interface was determined by means of a computer code and verified by Raman spectroscopy. Moreover, a prediction of the interfacial speciation of the deposited oxo- $\mathrm{V}(\mathrm{V})$ species on titania was achieved based on a deposition mechanism that fits very well the relevant experimental results. In situ Raman spectroscopy was used to verify the interfacial speciation of the wet $\mathrm{H}_{K} \mathrm{~V}_{X} \mathrm{O}_{Y}{ }^{Z-} / \mathrm{TiO}_{2}$ pastes as prepared by the EDF method and to monitor the temperature-dependent evolution of the Raman spectra at temperatures up to $430{ }^{\circ} \mathrm{C}$. It was shown that it is possible to design at the molecular level the synthesis of vanadia/titania catalysts, adopting the EDF method and following the formation of the vanadia site from the first (i.e., impregnation) to the final (i.e., calcination) step of the catalyst synthesis procedure. Hence, a controlled formation of specific vanadia species on titania surface is enabled, which, depending on the synthesis conditions, can result in specific catalyst characteristics and thus possibly different catalytic behavior for a specific reaction.

Particularly, it was found that the deposition of vanadates on titania surface takes place via the formation of two main species: (i) a mono-substituted inner sphere complex between one terminal hydroxyl of the titania surface and a monomeric species $\left(\mathrm{Ti}-\mathrm{OV}(\mathrm{OH})_{2} \mathrm{O}\right)$ and (ii) a disubstituted inner sphere complex between two terminal hydroxyls of the titania surface and one quadramer $\left((\mathrm{Ti}-\mathrm{O})_{2} \mathrm{~V}_{4} \mathrm{O}_{10}\right)$. At very high $\mathrm{pH}$ values $(>10)$, vanadium is deposited on titania exclusively in the form of the monomer species. As $\mathrm{pH}$ decreases, the contribution of quadramers on the deposition of $\mathrm{V}(\mathrm{V})$ on titania becomes gradually more significant. At a $\mathrm{pH}$ value of $\approx 8.5$, half of the deposited $\mathrm{V}$ is in the form of monomers, the other half being in the form of quadramers. At $\mathrm{pH}$ values lower than 6 , quadramers are the prevailing deposited vanadia species, although the predominant species in the solution are the decavanadate anions.

Tuning the structure of the vanadia species deposited on titania can enhance the catalytic performance of such materials [79]. Our findings show that a very strong interaction is developed between $\mathrm{V}(\mathrm{V})$ and titania from the first to the final step of the catalyst synthe- 
sis, which stabilizes bi-dimensional vanadia structures, thus ensuring high dispersion of the vanadia phase. The latter is expected to be associated with the excellent performance of such catalysts.

Supplementary Materials: The following are available online at https:/ /www.mdpi.com/2073-434 4/11/3/322/s1, Figure S1: (left) Variation of the concentration, [S] (mol/L), of the main vanadium species with the $\mathrm{pH}$, for two different total $\mathrm{V}$ concentrations and (right) the distribution of total vanadium among the different species in the solution $\left(\mathrm{I}=0.1 \mathrm{M} \mathrm{NaNO}_{3}\right)$, Figure S2: Amount of the $\mathrm{H}^{+}$ions adsorbed vs. the amount of the deposited $\mathrm{V}(\mathrm{V})$ for various $\mathrm{pH}$ values. Points represent experimental data and solid lines correspond to calculated curves on the basis of the deposition mechanism finally adopted in the simulation.

Author Contributions: Conceptualization, C.K., A.L., S.B. and K.B.; methodology, E.T., A.T. (Antonios Trimpalis) and A.T. (Athanasios Tsevis); software, E.T.; validation, A.T. (Antonios Trimpalis) and A.T. (Athanasios Tsevis); formal analysis, A.T. (Antonios Trimpalis) and A.T. (Athanasios Tsevis); investigation, E.T., A.T. (Antonios Trimpalis) and A.T. (Athanasios Tsevis); data curation, E.T., A.T. (Antonios Trimpalis) and A.T. (Athanasios Tsevis); writing—original draft preparation, K.B. and S.B.; writing-review and editing, C.K. and A.L.; visualization, C.K., A.L., S.B. and K.B.; supervision, S.B. and K.B. All authors have read and agreed to the published version of the manuscript.

Funding: This research received no external funding.

Data Availability Statement: Data is contained within the article or Supplementary Materials.

Conflicts of Interest: The authors declare no conflict of interest.

\section{Appendix A}

Table A1 contains all the species for the $\mathrm{H}_{\mathrm{K}} \mathrm{V}_{\mathrm{X}} \mathrm{O}_{\mathrm{Y}}{ }^{\mathrm{Z}-} / \mathrm{NaNO}_{3} / \mathrm{TiO}_{2}$ system, namely the surface (hydr)oxo groups of titania, the ion pairs of these groups with the ions of the indifferent electrolyte $\left(\mathrm{Na}^{+}, \mathrm{NO}_{3}{ }^{-}\right)$, and the deposited vanadium species. The formation of each surface species is defined in terms of components (columns), being components in solution, surface components (surface groups), and electrostatic components $\left(\exp \left(-\mathrm{F} \Psi_{\mathrm{i}} / \mathrm{RT}\right)\right.$, with $\mathrm{i}=0,1$, and 2, standing for the corresponding planes of the interface [64]). The concentration $[S]\left(\mathrm{mol} \mathrm{L}^{-1}\right)$ of a surface species can be calculated by reading the table horizontally and using Equation (1). All $\log K$ values are based on intrinsic constants, adjusted for activity corrections in the case of $I \neq 0$. The activity coefficients were estimated with the Davies equation (constant $=0.2$ ).

Table A1. Surface speciation for the deposition of vanadates on titania surface.

\begin{tabular}{|c|c|c|c|c|c|c|c|c|c|c|}
\hline \multirow{2}{*}{ Surface Species } & \multicolumn{4}{|c|}{ Dissolved Components } & \multicolumn{2}{|c|}{$\begin{array}{c}\text { Surface } \\
\text { Component }\end{array}$} & \multicolumn{3}{|c|}{ Electrostatic Components } & \multirow{2}{*}{$\begin{array}{c}\text { Intrinsic Formation } \\
\text { Constant } \\
(\log K)\end{array}$} \\
\hline & $\mathbf{H}^{+}$ & $\mathrm{Na}^{+}$ & $\mathrm{NO}_{3}^{-}$ & $\mathrm{HVO}_{4}{ }^{2-}$ & $\mathrm{TiO}^{0.35-}$ & $\mathrm{Ti}_{2} \mathrm{O}^{0.57-}$ & $\mathrm{e}^{-\mathrm{F} \Psi_{0} / \mathbf{R T}}$ & $\mathbf{e}^{-\mathrm{F} \Psi_{1} / \mathbf{R T}}$ & $\mathrm{e}^{-\mathrm{F} \Psi_{2} / \mathrm{RT}}$ & \\
\hline $\mathrm{Ti}_{2} \mathrm{O}^{0.57-}$ & 0 & 0 & 0 & 0 & 0 & 1 & 0 & 0 & 0 & - \\
\hline $\mathrm{TiO}^{0.35-}$ & 0 & 0 & 0 & 0 & 1 & 0 & 0 & 0 & 0 & - \\
\hline $\mathrm{Ti}_{2} \mathrm{OH}^{0.43+}$ & 1 & 0 & 0 & 0 & 0 & 1 & 1 & 0 & 0 & $\log K_{1}=7.8$ \\
\hline $\mathrm{TiOH}^{0.65+}$ & 1 & 0 & 0 & 0 & 1 & 0 & 1 & 0 & 0 & $\log K_{2}=4.6$ \\
\hline $\mathrm{Ti}_{2} \mathrm{O}^{0.57-}-\mathrm{Na}^{+}$ & 0 & 1 & 0 & 0 & 0 & 1 & 0 & 0.7 & 0.3 & $\log K_{N a}=-1.7$ \\
\hline $\mathrm{TiO}^{0.35-}-\mathrm{Na}^{+}$ & 0 & 1 & 0 & 0 & 1 & 0 & 0 & 0.7 & 0.3 & $\log K_{N a}=-1.7$ \\
\hline $\mathrm{Ti}_{2} \mathrm{OH}^{0.43+}-\mathrm{NO}_{3}{ }^{-}$ & 1 & 0 & 1 & 0 & 0 & 1 & 1 & -0.7 & -0.3 & $\log K_{1}+\log K_{N O 3}=5.6$ \\
\hline $\mathrm{TiOH}^{0.65+}-\mathrm{NO}_{3}^{-}$ & 1 & 0 & 1 & 0 & 1 & 0 & 1 & -0.7 & -0.3 & $\log K_{2}+\log K_{N O 3}=2.4$ \\
\hline $\mathrm{TiOV}(\mathrm{OH})_{2} \mathrm{O}^{0.65+}$ & 1 & 0 & 0 & 1 & 0 & 1 & 0.8 & -1.8 & 0 & $\log K_{T 1}=30.3 \pm 0.5$ \\
\hline$(\mathrm{TiO})_{2} \mathrm{~V}(\mathrm{OH})_{2}{ }^{2.3+}$ & 2 & 0 & 0 & 1 & 1 & 0 & 1.5 & -1.5 & 0 & $\log K_{T 2}=45.3 \pm 0.5$ \\
\hline$(\mathrm{TiO})_{2} \mathrm{~V}_{4} \mathrm{O}_{10}{ }^{0.7-}$ & 18 & 0 & 0 & 7 & 5 & 5 & 10 & -2 & -4 & $\log K_{T 3}=88 \pm 0.5$ \\
\hline Sum & $\Sigma_{1}$ & $\Sigma_{2}$ & $\Sigma_{3}$ & $\Sigma_{4}$ & $\Sigma_{5}$ & $\Sigma_{6}$ & $\Sigma_{7}$ & $\Sigma_{8}$ & $\Sigma_{9}$ & - \\
\hline
\end{tabular}




$$
\begin{aligned}
& \Sigma_{1}=\mathrm{H}^{+}(\mathrm{t})-\mathrm{OH}^{-}(\mathrm{t}) \\
& \Sigma_{2}=\mathrm{Na}^{+}(\mathrm{t}) \\
& \Sigma_{3}=\mathrm{NO}_{3}{ }^{-}(\mathrm{t}) \\
& \Sigma_{4}=\mathrm{HVO}_{4}{ }^{2-}(\mathrm{t}) \\
& \Sigma_{5}=\rho \mathrm{AN}_{\mathrm{S}, 1} \\
& \Sigma_{6}=\rho \mathrm{AN}_{\mathrm{S}, 2} \\
& \Sigma_{7}=\rho \mathrm{A} / \mathrm{F}\left(\sigma_{0}-\Sigma \mathrm{z}_{\mathrm{j}} \mathrm{FN}_{\mathrm{S}_{\mathrm{j}}}\right) \\
& \Sigma_{8}=\rho \mathrm{A} / \mathrm{F} \sigma_{1} \\
& \Sigma_{9}=\rho \mathrm{A} / \mathrm{F} \sigma_{2} \\
& \sigma_{0}=C_{1}\left(\Psi_{0}-\Psi_{1}\right) \\
& \sigma_{1}=C_{2}\left(\Psi_{1}-\Psi_{2}\right)-C_{1}\left(\Psi_{0}-\Psi_{1}\right) \\
& \sigma_{2}=C_{2}\left(\Psi_{2}-\Psi_{1}\right) \pm \frac{1}{2} \sqrt{8000 \varepsilon_{0} \varepsilon_{\mathrm{r}} \mathrm{RT}} \sqrt{\sum_{\mathrm{i}} \mathrm{C}_{\mathrm{i}}\left(\mathrm{e}^{-\mathrm{z}_{\mathrm{i}} \mathrm{F} \Psi_{2} / \mathrm{RT}}-1\right)}
\end{aligned}
$$

The parameters in the summation terms (A1)-(A12) are as follows: $\rho$, the solid concentration $\left(S C, \mathrm{~kg} \mathrm{~L}^{-1}\right) ; A$, the specific surface area $\left(S S A, \mathrm{~m}^{2} \mathrm{~kg}^{-1}\right) ; \mathrm{F}$, the Faraday constant $\left(\mathrm{C} \mathrm{mol}^{-1}\right) ; \sigma_{0}, \sigma_{1}$, and $\sigma_{2}$, the charges $\left(\mathrm{C} \mathrm{m}^{-2}\right)$ in the $0-, 1$-, and 2-planes, respectively; $\mathrm{z}_{\mathrm{j}}$, the charge of the surface reference groups $\mathrm{Ti}_{2} \mathrm{O}^{0.57-}$ and $\mathrm{TiOH}^{0.35-} ; \mathrm{N}_{S, j}$, the site densities $\left(\mathrm{mol} \mathrm{m}^{-2}\right.$ ) of the corresponding surface groups; $\Psi_{0}, \Psi_{1}$, and $\Psi_{2}$, the electrostatic potential $(V)$ of the $0-, 1-$, and 2-planes, respectively; $\mathrm{C}_{1}$, the capacitance $\left(\mathrm{C} \mathrm{V}^{-1} \mathrm{~m}^{-2}\right)$ of the layer between the 0 - and 1-plane; $C_{2}$, the capacitance $\left(\mathrm{C} \mathrm{V}^{-1} \mathrm{~m}^{-2}\right)$ of the layer between the 1 - and 2-plane; $\varepsilon_{0}$, the absolute dielectric constant $\left(\mathrm{C} \mathrm{V}^{-1} \mathrm{~m}^{-1}\right) ; \varepsilon_{\mathrm{r}}$, the relative dielectric constant; $\mathrm{R}$, the gas constant $\left(\mathrm{J} \mathrm{mol}^{-1} \mathrm{~K}^{-1}\right) ; \mathrm{T}$, the absolute temperature $(\mathrm{K}) ; \mathrm{C}_{\mathrm{i}}$, the concentrations of the dissolved electrolyte solution species with valence $\mathrm{z}_{\mathrm{i}}$. Values of the above-mentioned parameters can be found in Tables 3 (model A) and 4 of ref. [66].

\section{References}

1. Guerrero-Pérez, M.O. Supported, bulk and bulk-supported vanadium oxide catalysts: A short review with an historical perspective. Catal. Today 2017, 285, 226-233. [CrossRef]

2. Kaichev, V.V.; Chesalov, r.A.; Saraev, A.A.; Tsapina, A.M. A Mechanistic Study of Dehydrogenation of Propane over Vanadia-Titania Catalysts. J. Phys. Chem. C 2019, 123, 19668-19680. [CrossRef]

3. Kazerooni, H.; Darian, J.T.; Mortazavi, Y.; Khadadadi, A.A.; Asadi, R. Titania-Supported Vanadium Oxide Synthesis by Atomic Layer Deposition and Its Application for Low-Temperature Oxidative Dehydrogenation of Propane. Catal. Lett. 2020, 150, 2807-2822. [CrossRef]

4. Kraemer, S.; Rondinone, A.J.; Tsai, Y.-T.; Schwartz, V.; Overbury, S.H.; Idrobo, J.-C.; Wu, Z. Oxidative dehydrogenation of isobutane over vanadia catalysts supported by titania nanoshapes. Catal. Today 2016, 263, 84-90. [CrossRef] 
5. Zhang, W.; Innocenti, G.; Ferbinteanu, M.; Ramos-Fernandez, E.V.; Sepulveda-Escribano, A.; Wu, H.; Cavani, F.; Rothenberg, G.; Shiju, N.R. Understanding the oxidative dehydrogenation of ethyl lactate to ethyl pyruvate over vanadia/titania. Catal. Sci. Technol. 2018, 8, 3737-3747. [CrossRef]

6. Yun, D.; Herrera, J.E. A novel methodology for in situ redox active site titration of $\mathrm{TiO}_{2}$-supported vanadia during ethanol partial oxidation catalysis. J. Catal. 2017, 350, 72-85. [CrossRef]

7. Koivikko, N.; Laitinen, T.; Mouammine, A.; Ojala, S.; Keiski, R.L. Catalytic Activity Studies of Vanadia/Silica-Titania Catalysts in SVOC Partial Oxidation to Formaldehyde: Focus on the Catalyst Composition. Catalysts 2018, 8, 56. [CrossRef]

8. Liu, Z.; Zhang, R.; Wang, S.; Li, N.; Sima, R.; Liu, G.; Wu, P.; Zeng, G.; Li, S.; Sun, Y. Highly Efficient and Stable Vanadia-Titania-Sulfate Catalysts for Methanol Oxidation to Methyl Formate: Synthesis and Mechanistic Study. J. Phys. Chem. C 2016, 120, 6591-6600. [CrossRef]

9. Zhang, W.; Innocenti, G.; Oulego, P.; Gitis, V.; Wu, H.; Ensing, B.; Cavani, F.; Rothenberg, G.; Shiju, N.R. Highly Selective Oxidation of Ethyl Lactate to Ethyl Pyruvate Catalyzed by Mesoporous Vanadia-Titania. ACS Catal. 2018, 8, 2365-2374. [CrossRef]

10. Andrushkevich, T.V.; Kaichev, V.V.; Chesalov, Y.A.; Saraev, A.A.; Buktiyarov, V.I. Selective oxidation of ethanol over vanadia-based catalysts: The influence of support material and reaction mechanism. Catal. Today 2017, 279, 95-106. [CrossRef]

11. Ferretti, F.; Ribeiro, A.P.C.; Alegria, E.C.B.A.; Ferraria, A.M.; Kopylovich, M.N.; Guedes da Silva, M.F.C.; Marchetti, F.; Pombeiro, A.J.L. Synergistic catalytic action of vanadia-titania composites towards the microwave-assisted benzoin oxidation. Dalton Trans. 2019, 48, 3198-3203. [CrossRef]

12. Sethi, D.; Jada, N.; Tiwari, A.; Ramasamy, S.; Dash, T.; Pandey, S. Photocatalytic destruction of Escherichia coli in water by $\mathrm{V}_{2} \mathrm{O}_{5} / \mathrm{TiO}_{2}$. J. Photochem. Photobiol. B 2015, 144, 68-74. [CrossRef]

13. Lin, K.-S.; Lin, Y.-G.; Cheng, H.-W.; Haung, Y.-H. Preparation and characterization of V-Loaded titania nanotubes for adsorption/photocatalysis of basic dye and environmental hormone contaminated wastewaters. Catal. Today 2018, 307, 119-130. [CrossRef]

14. Chang, J.-H.; Wang, Y.-L.; Dong, C.-D.; Shen, S.-Y. Electrocatalytic Degradation of Azo Dye by Vanadium-Doped TiO 2 Nanocatalyst. Catalysts 2020, 10, 482. [CrossRef]

15. Guan, B.; Zhan, R.; Lin, H.; Huang, Z. Review of state of the art technologies of selective catalytic reduction of $\mathrm{NO}_{\mathrm{x}}$ from diesel engine exhaust. Appl. Therm. Eng. 2014, 66, 395-414. [CrossRef]

16. Forzatti, P. Present status and perspectives in de-NO $\mathrm{NCR}_{\mathrm{x}}$ catalysis. Appl. Catal. A 2001, 222, 221-236. [CrossRef]

17. Han, L.; Cai, S.; Gao, M.; Hasegawa, J.; Wang, P.; Zhang, J.; Shi, L.; Zhang, D. Selective Catalytic Reduction of $\mathrm{NO}_{x}$ with $\mathrm{NH}_{3}$ by Using Novel Catalysts: State of the Art and Future Prospects. Chem. Rev. 2019, 119, 10916-10976. [CrossRef]

18. Lai, J.-K.; Wachs, I.E. A Perspective on the Selective Catalytic Reduction (SCR) of $\mathrm{NO}$ with $\mathrm{NH}_{3}$ by $\mathrm{Supported}_{2} \mathrm{O}_{5}-\mathrm{WO}_{3} / \mathrm{TiO}_{2}$ Catalysts. ACS Catal. 2018, 8, 6537-6551. [CrossRef]

19. Gan, L.; Li, K.; Niu, H.; Peng, Y.; Chen, J.; Huang, Y.; Li, J. Simultaneous removal of $\mathrm{NO}_{x}$ and chlorobenzene on $\mathrm{V}_{2} \mathrm{O}_{5} / \mathrm{TiO}_{2}$ granular catalyst: Kinetic study and performance prediction. Front. Environ. Sci. Eng. 2021, 15, 70. [CrossRef]

20. Gallastegi-Villa, M.; Aranzabal, A.; Boukha, Z.; González-Marcos, J.A.; González-Velasco, J.R.; Martínez-Huerta, M.V.; Banares, M.A. Role of surface vanadium oxide coverage support on titania for the simultaneous removal of o-dichlorobenzene and $\mathrm{NO}_{\mathrm{x}}$ from waste incinerator flue gas. Catal. Today 2015, 254, 2-11. [CrossRef]

21. Xu, J.; Chen, G.; Guo, F.; Xie, J. Development of wide-temperature vanadium-based catalysts for selective catalytic reducing of $\mathrm{NO}_{\mathrm{x}}$ with ammonia: Review. Chem. Eng. J. 2018, 353, 507-518. [CrossRef]

22. Zhang, J.; Li, X.; Chen, P.; Zhu, B. Research Status and Prospect on Vanadium-Based Catalysts for $\mathrm{NH}_{3}$-SCR Denitration. Materials 2018, 11, 1632. [CrossRef]

23. Weckhuysen, B.M.; Keller, D.E. Chemistry, spectroscopy and the role of supported vanadium oxides in heterogeneous catalysis. Catal. Today 2003, 78, 25-46. [CrossRef]

24. Kompio, P.G.W.A.; Brückner, A.; Hipler, F.; Manoylova, O.; Auer, G.; Mestl, G.; Grünert, W. $\mathrm{V}_{2} \mathrm{O}_{5}-\mathrm{WO}_{3} / \mathrm{TiO}_{2}$ catalysts under

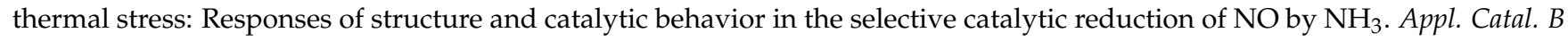
2017, 217, 365-377. [CrossRef]

25. Arnarson, L.; Falsig, H.; Rasmussen, S.B.; Lauritsen, J.V.; Moses, P.G. A complete reaction mechanism for standard and fast selective catalytic reduction of nitrogen oxides on low coverage $\mathrm{VO}_{\mathrm{x}} / \mathrm{TiO}_{2}(001)$ catalysts. J. Catal. 2017, 346, 188-197. [CrossRef]

26. Arnarson, L.; Rasmussen, S.B.; Falsig, H.; Lauritsen, J.V.; Moses, P.G. Coexistence of Square Pyramidal Structures of Oxo Vanadium (+5) and (+4) Species Over Low-Coverage $\mathrm{VO}_{\mathrm{X}} / \mathrm{TiO}_{2}(101)$ and (001) Anatase Catalysts. J. Phys. Chem. C 2015, 119, 23445-23452. [CrossRef]

27. Koust, S.; Arnarson, L.; Moses, P.G.; Li, Z.; Beinik, I.; Lauritsen, J.V.; Wendt, S. Facile embedding of single vanadium atoms at the anatase $\mathrm{TiO}_{2}$ (101) surface. Phys. Chem. Chem. Phys. 2017, 19, 9424-9431. [CrossRef] [PubMed]

28. Li, W.-Z.; Gao, F.; Li, Y.; Walter, E.D.; Liu, J.; Peden, C.H.F.; Wang, Y. Nanocrystalline Anatase Titania-Supported Vanadia Catalysts: Facet-Dependent Structure of Vanadia. J. Phys. Chem. C 2015, 119, 15094-15102. [CrossRef]

29. Marberger, A.; Ferri, D.; Elsener, M.; Krocher, O. The Significance of Lewis Acid Sites for the Selective Catalytic Reduction of Nitric Oxide on Vanadium-Based Catalysts. Angew. Chem. Int. Ed. 2016, 55, 11989-11994. [CrossRef]

30. Kwon, D.W.; Park, K.H.; Hong, S.C. Influence of $\mathrm{VO}_{\mathrm{x}}$ surface density and vanadyl species on the selective catalytic reduction of $\mathrm{NO}$ by $\mathrm{NH}_{3}$ over $\mathrm{VO}_{x} / \mathrm{TiO}_{2}$ for superior catalytic activity. Appl. Catal. A 2015, 499, 1-12. [CrossRef] 
31. Murkute, A.D.; Vanderwiel, D. Active Sites Evaluation of Vanadia Based Powdered and Extruded SCR Catalysts Prepared on Commercial Titania. Catal. Lett. 2015, 145, 1224-1236. [CrossRef]

32. Marberger, A.; Ferri, D.; Rentsch, D.; Krumeich, F.; Elsener, M.; Kröcher, O. Effect of $\mathrm{SiO}_{2}$ on co-impregnated $\mathrm{V}_{2} \mathrm{O}_{5} / \mathrm{WO}_{3} / \mathrm{TiO}_{2}$ catalysts for the selective catalytic reduction of $\mathrm{NO}$ with $\mathrm{NH}_{3}$. Catal. Today 2019, 320, 123-132. [CrossRef]

33. Liu, X.; Chen, H.; Wu, X.; Cao, L.; Jiang, P.; Yu, Q.; Ma, Y. Effects of $\mathrm{SiO}_{2}$ modification on the hydrothermal stability of the $\mathrm{V}_{2} \mathrm{O}_{5} / \mathrm{WO}_{3}-\mathrm{TiO}_{2} \mathrm{NH}_{3}$-SCR catalyst: $\mathrm{TiO}_{2}$ structure and vanadia species. Catal. Sci. Technol. 2019, 9, 3711-3720. [CrossRef]

34. Shutilov, R.A.; Shutilov, A.A.; Zenkovets, G.A. Nanocrystalline $\mathrm{V}_{2} \mathrm{O}_{5}, \mathrm{WO}_{3} /\left(\mathrm{CeO}_{2}-\mathrm{TiO}_{2}\right)$ and $\mathrm{V}_{2} \mathrm{O}_{5}, \mathrm{WO}_{3} /\left(\mathrm{Y}_{2} \mathrm{O}_{3}-\mathrm{TiO}_{2}\right)$ catalysts with enhance thermal stability and activity in the reduction of $\mathrm{NO}$ with $\mathrm{NH}_{3}$ into $\mathrm{N}_{2}$. Mater. Today Proc. 2017, 4, 11490-11494. [CrossRef]

35. Zhang, S.; Liu, S.; Hu, W.; Zhu, X.; Qu, R.; Wu, W.; Zheng, C.; Gao, X. New insight into alkali resistance and low temperature activation on vanadia-titania catalysts for selective catalytic reduction of NO. Appl. Surf. Sci. 2019, 466, 99-109. [CrossRef]

36. Marberger, A.; Ferri, D.; Elsener, M.; Sagar, A.; Artner, C.; Schermanz, K.; Kröcher, O. Relationship between structures and activities of supported metal vanadates for the selective catalytic reduction of $\mathrm{NO}$ by $\mathrm{NH}_{3}$. Appl. Catal. B 2017, 218, 731-742. [CrossRef]

37. Marberger, A.; Elsener, M.; Nuguid, R.J.G.; Ferri, D.; Kröcher, O. Thermal activation and aging of a $\mathrm{V}_{2} \mathrm{O}_{5} / \mathrm{WO}_{3}-\mathrm{TiO}_{2}$ catalyst for the selective catalytic reduction of $\mathrm{NO}$ with $\mathrm{NH}_{3}$. Appl. Catal. A 2019, 573, 64-72. [CrossRef]

38. Hess, C.; Waleska, P.; Ratzka, M.; Janssens, T.V.W.; Rasmussen, S.B.; Beato, P. Hierarchical Vanadia Model Catalysts for Ammonia Selective Catalytic Reduction. Top. Catal. 2017, 60, 1631-1640. [CrossRef]

39. Shen, J.; Hess, C. High Surface Area $\mathrm{VO}_{\mathrm{x}} / \mathrm{TiO}_{2} / \mathrm{SBA}-15$ Model Catalysts for Ammonia SCR Prepared by Atomic Layer Deposition. Catalysts 2020, 10, 1386. [CrossRef]

40. He, Y.; Ford, M.E.; Zhu, M.; Liu, Q.; Tumuluri, U.; Wu, Z.; Wachs, I.E. Influence of catalyst synthesis method on selective catalytic reduction (SCR) of $\mathrm{NO}$ by $\mathrm{NH}_{3}$ with $\mathrm{V}_{2} \mathrm{O}_{5}-\mathrm{WO}_{3} / \mathrm{TiO}_{2}$ catalysts. Appl. Catal. B 2016, 193, 141-150. [CrossRef]

41. Bourikas, K.; Kordulis, C.; Lycourghiotis, A. The role of the liquid-Solid interface in the preparation of supported catalysts. Catal. Rev. Sci. Eng. 2006, 48, 363-444. [CrossRef]

42. Bourikas, K.; Kordulis, C.; Lycourghiotis, A. Titanium Dioxide (Anatase and Rutile): Surface Chemistry, Liquid-Solid Interface Chemistry, and Scientific Synthesis of Supported Catalysts. Chem. Rev. 2014, 114, 9754-9823. [CrossRef]

43. Munnik, P.; de Jongh, P.E.; de Jong, K.P. Recent Developments in the Synthesis of Supported Catalysts. Chem. Rev. 2015, 115, 6687-6718. [CrossRef]

44. Carrier, X.; Royer, S.; Marceau, E. Synthesis of metal oxide catalysts. In Metal Oxides in Heterogeneous Catalysis; Védrine, J.C., Ed.; Elsevier: Amsterdam, The Netherlands, 2018; pp. 43-103. [CrossRef]

45. Carrier, X.; Marceau, E.; Che, M. Physical techniques and catalyst preparation: Determining the interactions of transition-metal complexes with oxide surfaces. Pure Appl. Chem. 2006, 78, 1039-1055. [CrossRef]

46. de Jong, K.P. Synthesis of Solid Catalysts; Wiley: New York, NY, USA, 2008. [CrossRef]

47. Mehrabadi, B.A.T.; Eskandari, S.; Khan, U.; White, R.D.; Regalbuto, J.R. A Review of Preparation Methods for Supported Metal Catalysts. Adv. Catal. 2017, 61, 1-35. [CrossRef]

48. Marceau, E.; Bonneviot, L.; Dzwigaj, S.; Lambert, J.-F.; Louis, C.; Carrier, X. Interfacial Coordination Chemistry for Catalyst Preparation. J. Catal. 2021, in press. [CrossRef]

49. Panagiotou, G.D.; Petsi, T.; Bourikas, K.; Kalampounias, A.G.; Boghosian, S.; Kordulis, C.; Lycourghiotis, A. Interfacial Impregnation Chemistry in the Synthesis of Molybdenum Catalysts supported on Titania. J. Phys. Chem. C 2010, 114, 11868-11879. [CrossRef]

50. Petsi, T.; Panagiotou, G.D.; Bourikas, K.; Kordulis, C.; Voyiatzis, G.A.; Lycourghiotis, A. Interfacial Impregnation Chemistry in the Synthesis of Chromium Catalysts Supported on Titania. ChemCatChem 2011, 3, 1072-1082. [CrossRef]

51. Bourikas, K.; Stavropoulos, J.; Garoufalis, C.S.; Kordulis, C.; Petsi, T.; Lycourghiotis, A. Interfacial Impregnation Chemistry in the Synthesis of Nickel Catalysts Supported on Titania. Chem. Eur. J. 2011, 17, 1201-1213. [CrossRef] [PubMed]

52. Petsi, T.; Panagiotou, G.D.; Garoufalis, C.S.; Kordulis, C.; Stathi, P.; Deligiannakis, Y.; Lycourghiotis, A.; Bourikas, K. Interfacial Impregnation Chemistry in the Synthesis of Cobalt Catalysts Supported on Titania. Chem. Eur. J. 2009, 15, 13090-13104. [CrossRef]

53. Panagiotou, G.D.; Petsi, T.; Bourikas, K.; Kordulis, C.; Lycourghiotis, A. The Interfacial Chemistry of the Impregnation Step Involved in the Preparation of Tungsten (VI) Supported Titania Catalysts. J. Catal. 2009, 262, 266-279. [CrossRef]

54. Rasmussen, S.B.; Abrams, B.L. Fundamental chemistry of V-SCR catalysts at elevated temperatures. Catal. Today 2017, 297, 60-63. [CrossRef]

55. Fan, F.; Feng, Z.; Li, C. UV Raman spectroscopic studies on active sites and synthesis mechanisms of transition metal-containing microporous and mesoporous materials. Acc. Chem. Res. 2010, 43, 378-387. [CrossRef]

56. Giakoumelou, I.; Fountzoula, C.; Kordulis, C.; Boghosian, S. Molecular structure and catalytic activity of $\mathrm{V}_{2} \mathrm{O}_{5} / \mathrm{TiO}_{2}$ catalysts

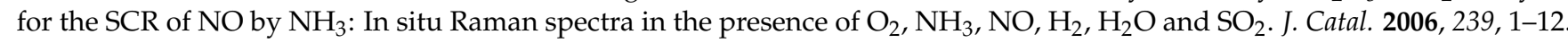
[CrossRef]

57. Kryukova, G.N.; Zenkovets, G.A.; Mestl, G.; Schlögl, R. Structural study of titanium-doped vanadia and vanadium-doped titania catalysts. React. Kinet. Catal. Lett. 2003, 80, 161-169. [CrossRef]

58. Wachs, I.E. Catalysis science of supported vanadium oxide catalysts. Dalton Trans. 2013, 42, 11762-11769. [CrossRef] 
59. Martinez-Huerta, M.V.; Fierro, J.L.G.; Banaraes, M.A. Monitoring the states of vanadium oxide during the transformation of TiO ${ }_{2}$ anatase-to-rutile under reactive environments: $\mathrm{H}_{2}$ reduction and oxidative dehydrogentation of ethane. Catal. Commun. 2009, 11, 15-19. [CrossRef]

60. Tribalis, A.; Panagiotou, G.D.; Tsilomelekis, G.; Kalampounias, A.G.; Bourikas, K.; Kordulis, C.; Boghosian, S.; Lycourghiotis, A. Temperature -dependent evolution of the molecular configuration of oxo-tungsten(VI) species deposited on the surface of titania. J. Phys. Chem. C 2014, 118, 11319-11332. [CrossRef]

61. Tsilomelekis, G.; Panagiotou, G.D.; Stathi, P.; Kalampounias, A.G.; Bourikas, K.; Kordulis, C.; Deligiannakis, Y.; Boghosian, S.; Lycourghiotis, A. Molybdena deposited on titania by equilibrium deposition filtration: Structural evolution of oxo-molybdenum(V)) sites with temperature. Phys. Chem. Chem. Phys. 2016, 18, 23980-23989. [CrossRef]

62. Andriopoulou, C.; Boghosian, S. Tuning the configuration of dispersed oxometallic sites in supported transition metal oxide catalysts: A temperature dependent Raman study. Catal. Today 2019, 336, 74-83. [CrossRef]

63. Andriopoulou, C.; Boghosian, S. Molecular structure and termination configuration of Oxo-Re(VII) catalyst sites supported on Titania. Catal. Today 2020, 355, 665-677. [CrossRef]

64. Tella, E.; Panagiotou, G.D.; Petsi, T.; Bourikas, K.; Kordulis, C.; Lycourghiotis, A. The mechanism of retention of vanadium oxo-species at the "titanium oxide/aqueous solution" interface. Global NEST J. 2010, 12, 231-238. [CrossRef]

65. Gustafsson, J.P. Visual MINTEQ, version 2.40; Department of Land and Water Resources Engineering, Royal Institute of Technology: Stockholm, Sweden, 2005.

66. Panagiotou, G.D.; Petsi, T.; Bourikas, K.; Garoufalis, C.S.; Tsevis, A.; Spanos, N.; Kordulis, C.; Lycourghiotis, A. Mapping the surface (hydr)oxo-groups of titanium oxide and its interface with an aqueous solution: The state of the art and a new approach. Adv. Colloid Interface Sci. 2008, 142, 20-42. [CrossRef] [PubMed]

67. Nakamoto, K. Infrared and Raman Spectra of Inorganic and Coordination Compounds, 6th ed.; Wiley-Interscience: New York, NY, USA, 2009.

68. Boghosian, S. Vibrational Modes and Structure of Vanadium (V) Complexes in $\mathrm{M}_{2} \mathrm{SO}_{4}-\mathrm{V}_{2} \mathrm{O}_{5}$ (M= K, Cs) Molten Salt Mixtures. J. Chem. Soc. Faraday Trans. 1998, 94, 3463-3469. [CrossRef]

69. Aureliano, M.; Ohlin, C.A.; Vieira, M.O.; Marques, M.P.M.; Casey, W.H.; Batista de Carvalho, L.A.E. Characterization of decavanadate and decaniobate solutions by Raman spectroscopy. Dalton Trans. 2016, 45, 7391-7399. [CrossRef]

70. Busca, G. Differentiation of mono-oxo and polyoxo and of monomeric and polymeric vanadate, molybdate and tungstate species in metal oxide catalysts by IR and Raman spectroscopy. J. Raman Spectrosc. 2002, 33, 348-358. [CrossRef]

71. Went, G.T.; Oyama, S.T.; Bell, A.T. Laser Raman spectroscopy of supported vanadium oxide catalysts. J. Phys. Chem. 1990, 94, 4240-4246. [CrossRef]

72. Wachs, I.E.; Weckhuysen, B.M. Structure and reactivity of surface vanadium oxide species on oxide supports. Appl. Catal. A 1997, 157, 67-90. [CrossRef]

73. Christodoulakis, A.; Machli, M.; Lemonidou, A.A.; Boghosian, S. Molecular structure and reactivity of vanadia-based catalysts for propane oxidative dehydrogenation studied by in situ Raman spectroscopy and catalytic activity measurements. J. Catal. 2004, 222, 293-306. [CrossRef]

74. Bulushev, D.; Rainone, F.; Kiwi-Minsker, L.; Renken, A. Influence of potassium doping on the formation of vanadia species in $\mathrm{V} /$ Ti oxide catalysts. Langmuir 2001, 17, 5276-5282. [CrossRef]

75. Due-Hansen, J.; Boghosian, S.; Kustov, A.; Fristrup, P.; Tsilomelekis, G.; Ståhl, K.; Christensen, C.H.; Fehrmann, R. Vanadia-based SCR catalysts supported on tungstated and sulfated zirconia: Influence of doping with potassium. J. Catal. 2007, 251, 459-473. [CrossRef]

76. Calatayud, M.; Minot, C. Effect of alkali doping on a $\mathrm{V}_{2} \mathrm{O}_{5} / \mathrm{TiO}_{2}$ catalyst from periodic DFT calculations. J. Phys. Chem. C 2007, 111, 6411-6417. [CrossRef]

77. Lewandowska, A.E.; Calatayud, M.; Lozano-Diz, E.; Minot, C.; Banares, M.A. Combining theoretical description with experimental in situ studies on the effect of alkali additives on the structure and reactivity of vanadium oxide supported catalysts. Catal. Today 2008, 139, 209-213. [CrossRef]

78. Tsilomelekis, G.; Boghosian, S. An operando Raman study of molecular structure and reactivity of molybdenum(VI) oxide supported on anatase for the oxidative dehydrogenation of ethane. Phys. Chem. Chem. Phys. 2012, 14, 2216-2228. [CrossRef]

79. Lian, Z.; Li, Y.; Shan, W.; He, H. Recent Progress on Improving Low-Temperature Activity of Vanadia-Based Catalysts for the Selective Catalytic Reduction of $\mathrm{NO}_{x}$ with Ammonia. Catalysts 2020, 10, 1421. [CrossRef] 